This item was submitted to Loughborough's Research Repository by the author.

Items in Figshare are protected by copyright, with all rights reserved, unless otherwise indicated.

\title{
The contingent roles of R\&D-sales versus R\&D-marketing cooperation in new-product development of business-to-business firms
}

PLEASE CITE THE PUBLISHED VERSION

https://doi.org/10.1016/j.ijresmar.2016.05.008

\section{PUBLISHER}

(C) Elsevier

VERSION

AM (Accepted Manuscript)

\section{PUBLISHER STATEMENT}

This work is made available according to the conditions of the Creative Commons Attribution-NonCommercialNoDerivatives 4.0 International (CC BY-NC-ND 4.0) licence. Full details of this licence are available at: https://creativecommons.org/licenses/by-nc-nd/4.0/

\section{LICENCE}

CC BY-NC-ND 4.0

\section{REPOSITORY RECORD}

Homburg, Christian, Sascha Alavi, Thomas Rajab, and Jan Wieseke. 2019. "The Contingent Roles of R\&dsales Versus R\&d-marketing Cooperation in New-product Development of Business-to-business Firms". figshare. https://hdl.handle.net/2134/33439. 


\section{The Contingent Roles of R\&D-Sales versus R\&D-Marketing Cooperation in New Product Development of Business-to-Business Firms}

Christian Homburg, Sascha Alavi, Thomas Rajab, and Jan Wieseke

forthcoming January 2017, International Journal of Research in Marketing

Christian Homburg (homburg@bwl.uni-mannheim.de) is Professor of Business Administration and Marketing at the University of Mannheim, Germany. Sascha Alavi (sascha.alavi@rub.de) is Assistant Professor at the Mario Rese inspired Sales \& Marketing Department at the University of Bochum, Germany. Thomas Rajab (thomasrajab@yahoo.de) is Business Consultant at the Boston Consulting Group, Germany. Jan Wieseke (jan.wieseke@rub.de) is Professor of Business Administration, Sales, and Marketing at the Mario Rese inspired Sales \& Marketing Department at the University of Bochum, Germany.

Please address all correspondence to: Jan Wieseke, Sales \& Marketing Department, University of Bochum, Universitaetsstrasse 150, 44780 Bochum (Germany), telephone +49-234-32-22897, fax +49 -234-32-14272, jan.wieseke@rub.de. 


\section{Highlighs}

- The present paper represents the first study exploring the effectiveness of R\&D-marketing as compared to R\&D-sales cooperation for new product development under different market and organizational circumstances in business-to-business settings

- The effect of R\&D-marketing and R\&D-sales cooperation on new product advantage varies significantly depending on the velocity of the market environment, company strategy and $\mathrm{R} \& \mathrm{D}$ characteristics

- Using a cross-industry dyadic data set of 230 industrial firms, we show that R\&D-marketing cooperation exhibits a stronger association with new-product advantage if firms follow a cost leadership strategy, if R\&D holds high power levels regarding new-product decisions, and if $\mathrm{R} \& \mathrm{D}$ collectivism is strongly pronounced

- Firms might foster R\&D-sales cooperation if technological turbulence is strongly pronounced in the market, if the firm follows a differentiation strategy and if R\&D is influential in firmwide budgeting decisions 


\title{
The Contingent Roles of R\&D-Sales versus R\&D-Marketing Cooperation in New-Product Development of Business-to-Business Firms
}

\begin{abstract}
This investigation explores the effectiveness of R\&D-marketing cooperation as compared to R\&D-sales cooperation for new-product development under different market and organizational circumstances in business-to-business settings. Using a cross-industry dyadic data set of 230 industrial firms, we show that the effects of R\&D-marketing and R\&D-sales cooperation on new-product advantage vary significantly, depending on the velocity of the market environment, company strategy, and R\&D characteristics. Specifically, R\&D-marketing cooperation exhibits a stronger association with new-product advantage if firms follow a cost leadership strategy, if R\&D holds high power levels regarding new-product decisions, and if R\&D collectivism is strongly pronounced. Conversely, R\&D-sales cooperation exhibits a stronger effect on newproduct advantage if technological turbulence is pronounced in the market, if the firm follows a differentiation strategy, and if $R \& D$ is influential in firm-wide budgeting decisions. These results may help firms decide which $R \& D$ cooperation type might be encouraged to maximize innovation success in a given situation.
\end{abstract}

Keywords: sales; marketing; research and development; cross-functional cooperation; newproduct development. 
Sixty-eight percent of the sales managers in a cross-industry, cross-national survey state that for effective new-product development $R \& D$ should cooperate with marketing as well as sales. ${ }^{1}$

\section{Introduction}

Marketing research and practice now regard integration of the voice of the customer into the innovation process as critical to avert new-product failures and foster innovation success (Griffin \& Hauser 1996). The innovation process might incorporate the voice of the customer by encouraging cooperation of R\&D with either marketing or sales (Ernst, Hoyer, \& Rübsaamen 2010). As our introductory quote illustrates, a majority of sales managers hold the view that in addition to the marketing department, the sales department might provide an important contribution to a successful innovation process. In light of the high relevance of including customer knowledge in innovation processes, our primary goal is to compare the effectiveness of R\&D-marketing cooperation with R\&D-sales cooperation for relative new-product advantage under varying organizational and market conditions in a business-to-business context.

While prior research has intensively investigated R\&D-marketing cooperation, academic literature on R\&D-sales cooperation is scarce (Joshi 2010). A key study on collaborations with $\mathrm{R} \& \mathrm{D}$ is the first—and to our best knowledge the only—study to analyze the effect of R\&D-sales cooperation on new-product performance (Ernst, Hoyer, \& Rübsaamen 2010). That investigation shows that integrating $\mathrm{R} \& \mathrm{D}$ with marketing or sales might increase innovation success, but does not account for contingency factors of the relationships between R\&D-sales/R\&D-marketing cooperation and new-product performance. Therefore, it remains unclear whether R\&D-sales cooperation or R\&D-marketing cooperation is more effective in promoting new-product success under certain market or organizational circumstances.

\footnotetext{
${ }^{1}$ Survey of a professional market research agency (usamp), which we employed; see Web Appendix W8.
} 
This research question may hold implications for the marketing literature on crossfunctional cooperation in innovation processes. While the prevailing view posits that to achieve new-product success companies should rely on both R\&D-sales and R\&D-marketing cooperation (Ernst, Hoyer \& Rübsaamen 2010), we propose that companies may employ either R\&D-sales or R\&D-marketing cooperation, depending on market and organizational contingency factors. We thus apply a contingency approach to cross-functional cooperation (Troy, Hirunyawipada, \& Paswan 2008; Olson, Walker, \& Ruekert 1995) based on the key notion that the voice of the customer might be heard in the innovation process through either marketing or sales. Figure 1 provides an overview of the different research perspectives on R\&D-sales as compared to R\&D-marketing cooperation.

Simultaneously, our research question might hold relevance for firms, as in the face of financial resource constraints firms may face a trade-off between fostering R\&D-sales cooperation and R\&D-marketing cooperation, forcing them to decide for one cooperation type. However, in different situations, the impact on innovation success of R\&D-sales as compared to R\&D-marketing cooperation may vary strongly. For instance, we find that for high technological turbulence R\&D-sales cooperation is highly effective whereas $R \& D$-marketing cooperation is rather ineffective. Hence, our results may help firms decide which R\&D cooperation might be encouraged to maximize innovation success in a given situation.

To investigate this research question, we developed a conceptual framework comparing the contingent influence of both R\&D interfaces on relative new-product advantage. More specifically, we conceptualize the effect of both R\&D-marketing and R\&D-sales cooperation on relative new-product advantage to depend on market environment factors (technological turbulence, competitive intensity) and company strategy factors (differentiation strategy, cost 
leadership strategy) as well as characteristics of the $R \& D$ department ( $R \& D$ culture, $R \& D$

power). Drawing on the resource-based view (Verona 1999) and the thought-world concept

(Homburg \& Jensen 2007), we propose that knowledge and competences specific to each

department enhance the effectiveness of one cooperation type relative to the other contingent on

these market, company strategy, and R\&D factors.

Figure 1 - Research Perspectives on R\&D-Sales and Marketing Cooperation

\begin{tabular}{|c|c|c|}
\hline $\begin{array}{c}\text { Marketing and Sales as } \\
\text { one Entity }\end{array}$ & $\begin{array}{c}\text { Perspectives on Cross-Functional } \\
\text { Cooperation of R\&D } \\
\text { with Marketing and Sales }\end{array}$ & $\begin{array}{l}\text { Marketing and Sales as } \\
\text { two Entities }\end{array}$ \\
\hline $\begin{array}{l}\text { Conceptually treat marketing and sales as } \\
\text { equal in new product development }\end{array}$ & Basic Philosophy & $\begin{array}{l}\text { Marketing and sales should not be treated } \\
\text { equally in new product development }\end{array}$ \\
\hline $\begin{array}{c}\text { "Empirical studies have typically not } \\
\text { distinguished between marketing and sales } \\
\text { but have subsumed both under the term } \\
\text { "marketing organization"'" } \\
\text { (Homburg, Jensen, and Krohmer 2008, p. 133) }\end{array}$ & Quote Regarding Basic Philosophy & $\begin{array}{l}\text { „The role of sales in new product } \\
\text { development needs to be explicitly } \\
\text { examined beyond that of marketing” } \\
\text { (Ernst, Hoyer, and Rübsaamen } 2010, \text { p. 80) }\end{array}$ \\
\hline $\begin{array}{l}\text { Selected articles: } \\
\text { - Ruekert and Walker } 1987 \\
\text { - Song and Montoya-Weiss } 2001 \\
\text { - Moenaert et al. } 1995 \\
\text { - } \text { Moenaert and Souder } 1990 \\
\text { - Olson et al. } 2001 \\
\text { - Song and Parry } 1997 \\
\text { - } \ldots\end{array}$ & Related Literature & $\begin{array}{l}\text { Only article: } \\
\text { • Ernst, Hoyer, and Rübsaamen (2010) }\end{array}$ \\
\hline & & $\begin{array}{l}\quad \text { RESEARCH GAP } \\
\text { Contingency Perspective of R\&D- } \\
\text { Sales/Marketing Cooperation: } \\
\text { Under what contingencies should } \\
\text { companies rely on R\&D-Sales versus } \\
\text { R\&D-Marketing cooperation? } \\
\text { Basic Philosophy: Marketing and sales } \\
\text { should not be treated equally in new } \\
\text { product development and their effects } \\
\text { should be differentiated for various } \\
\text { contingency factors }\end{array}$ \\
\hline
\end{tabular}

To test our research model, we collected survey data from key informants of 230 businessto-business companies across a range of industries. For each firm, we matched responses of one senior executive from the market side (e.g., head of sales) with one senior executive from the technical side (e.g., head of R\&D). This approach improves the reliability of our measurement and limits the likelihood of common method bias as an explanation for relationships discovered 
in our model. In addition, we obtained objective data from company records to validate our key performance measures. In confirmation of the proposition of a contingency account of R\&Dmarketing and R\&D-sales cooperation, we find that depending on the market environment, company strategies, and R\&D characteristics, the influence of the two cooperation types on relative new-product advantage differs significantly.

Our study makes two additions to marketing research on cross-functional cooperation. Our primary research contribution is a new perspective on the role of marketing and sales in newproduct development processes of business-to-business firms. In acknowledgement of fundamental differences between the sales and marketing departments in terms of knowledge and work orientations, we propose and empirically verify a contingency account of R\&D-marketing and R\&D-sales cooperation in the new-product development process. Underlining the need for a contingency perspective, researchers have concluded that although "cross-functional cooperation may indeed have a direct impact on success, the combination of cooperation with other variables may be of greater importance” (Troy, Hirunyawipada, \& Paswan 2008, p. 132). Our second contribution relates to the limited investigation of R\&D-sales cooperation in an innovation context (Ernst, Hoyer, \& Rübsaamen 2010) in that we identify contingency factors influencing the effectiveness of the relationship between R\&D-sales cooperation and relative new-product advantage.

Our findings may have implications for the involvement of sales and marketing in innovation processes of industrial firms. Engaging in cooperation in innovation processes is costly for R\&D in terms of time, coordination effort, and potential frictions. In this respect, our results indicate that unconditionally fostering the cooperation of R\&D with both marketing and sales may be neither necessary nor cost-effective. Instead, firms might carefully evaluate which 
department is more suited to cooperation with R\&D given the particular market and organizational circumstances. In this vein, we provide recommendations for strengthening either R\&D-sales or R\&D-marketing cooperation, depending on the situation.

\section{Conceptual framework}

\subsection{Resource-based view and thought-world differences}

Our conceptualization for the differential effects of R\&D-sales and R\&D-marketing cooperation on relative new-product advantage rests on two bases. First, we rely on the resourcebased view, which posits that resources necessary for innovation success are dispersed across organizational functions and which has been regularly applied to cross-functional cooperation research (Verona 1999; Olson, Walker, \& Ruekert 1995). Second, we base our argumentation on the thought-world concept (Dougherty 1992), which distinguishes the marketing and sales functions in terms of basic orientations, competences, and knowledge bases (Homburg \& Jensen 2007).

\subsubsection{The resource-based view}

Theoretical support for predictions that link cross-functional cooperation to product innovation success can be drawn from the resource-based view (Ruekert \& Walker 1987). For new-product development, the requisite resources are spread across the organization. In particular, specialist knowledge and informational resources tend to reside at the level of functionally differentiated subunits like sales, marketing, and R\&D (Krasnikov \& Jayachandran 2008). The dispersion and complementarity of functional resources lead to the argument that innovation processes benefit from cross-functional coupling that allows the cooperation of subunit-specific skills and knowledge. In other words, the more strongly firms encourage cooperation between functional subunits in innovation processes, the more likely the functions 
are to share specific resources and hence the better new products should actually perform (Troy, Hirunyawipada, \& Paswan 2008).

While the prior reasoning elucidates why cooperation between functions is generally beneficial for innovation processes, which particular function R\&D should cooperate with remains unclear. For a cooperation to be instrumental, two requirements have to be met: the cooperation partner must be endowed with the appropriate resources to fulfill the respective task, and these resources have to be exchanged smoothly, without friction, between the cooperation partners to effectively accomplish the respective task (Pfeffer \& Salanczik 1978). From this reasoning, it follows that to achieve innovation success, $R \& D$ should cooperate with the department (1) that is endowed with the appropriate resources for new-product development under the given circumstances and (2) with which information exchange is more effective (Olson, Walker, \& Ruekert 1995). In this respect, the thought-world concept helps to fathom resource endowments and exchange effectiveness of the marketing and sales departments to distinguish the optimal partner for R\&D under different conditions.

\subsubsection{Linking the resource-based view with the thought worlds of marketing and sales}

A thought world comprises a community of persons engaged in a certain domain of activity and holding a common understanding of that activity (Dougherty 1992). The thoughtworld concept proposes that departments develop interpretative schemes to guide perceptions and actions of department members. Constituent facets of thought worlds are a "fund of knowledge" — what departments know — and "systems of meaning"—-how departments know (Dougherty 1992, p. 182).

Academia has established that marketing and sales are discrete functions with different responsibilities and task foci (Homburg, Jensen, \& Krohmer 2008). Moreover, these distinct 
thought worlds entail different resource endowments in terms of knowledge and work orientation. Owing to these diverging resource endowments, certain market or organizational environments may render cooperation between either R\&D-sales or R\&D-marketing more effective for relative new-product advantage. In developing our hypotheses, we elaborate on the specific thought-world differences between marketing and sales and how these translate to differential effectiveness of R\&D-sales cooperation and R\&D-marketing cooperation under different contingencies.

\subsection{Description of conceptual model}

\subsubsection{Basic linkages in the framework}

Our conceptual model reflects as a basic link the direct effect of R\&D-marketing as well as R\&D-sales cooperation on relative new-product advantage (Figure 2). In line with prior research, we define relative new-product advantage as our key new-product development outcome, in terms of the degree to which the product has unique attributes and is superior to rival products in quality and technical performance (Song \& Montoya-Weiss 2001). Thus, newproduct advantage is a measure of innovation success relative to competitive offers. Prior research views the relative nature of new-product advantage as a key aspect of this concept, as innovation success needs to be assessed on the basis of rival offerings in the market. We chose new-product advantage as our key dependent variable because prior research has firmly established it as a valid measurement of new-product success and found it to exhibit high predictive validity regarding firm outcome measures (Li \& Calantone 1998; Song \& MontoyaWeiss 2001). In this respect, prior research revealed that relative new-product advantage is positively associated with perceived product performance (Edgett, Shipley, \& Forbes 1992), firm 
market performance (Li \& Calantone 1998), and relative product profitability, firm market share, and relative sales (Song \& Parry 1997).

Furthermore, employing a behavioral perspective (Gupta, Raj, \& Wilemon 1986), we define R\&D-sales (R\&D-marketing) cooperation as intensity of information sharing and interaction concerning key tasks in the new-product development process between $R \& D$ and sales (marketing) (Ernst, Hoyer, \& Rübsaamen 2010).

\subsubsection{Contingency factors}

Implementing the contingency approach in our conceptual model, we include market and company factors that moderate the relationship of both R\&D-sales and R\&D-marketing cooperation on relative new-product advantage. We derive the moderators for the conceptual framework on the basis of the strategic fit paradigm — a core concept regarding the interdependence of organizational structure, environment, and strategy (Ginsberg \& Venkatraman 1985). The strategic fit approach suggests that to maximize corporate performance, a company's structure and strategy needs to align with the external environment. On the basis of this notion, we derive moderators in the categories of market environment, company strategy, culture of the R\&D department, and R\&D power.

We focus on competitive intensity and technological turbulence as the major descriptors of a company’s market environment. While competitive intensity captures the frequency and impact of competitor moves that a firm faces in the market, technological turbulence comprises the pace and significance of product-related technological changes in the industry (Jaworski \& Kohli 1993). Regarding companies’ strategic focus, we include differentiation strategy and cost leadership strategy in the conceptual framework (Porter 1980). Differentiation strategy, which is a company's positioning approach in the market, we define as the extent to which a company's 
market positioning focuses on providing superior product value to the customer. Unlike differentiation strategy, with its external focus, cost leadership strategy concerns companies' internal organization, and we define it as the extent to which a company attempts to rationalize organizational processes to realize cost-saving potentials.

With regard to characteristics of the R\&D department, we examine R\&D's cultural facets as well as its domain-specific power within the organization. Concerning R\&D culture, we consider power distance and level of collectivism as two major cultural dimensions from Hofstede's seminal conceptualization of culture pertaining to how individuals view social relationships in the department (Hofstede \& Bond 1984). Power distance refers to how important department members consider hierarchical aspects to be and specifically is understood as the extent to which less powerful members accept and expect that power is distributed unequally (Hofstede \& Bond 1984). Level of collectivism is the degree to which cooperation of department members in groups is appreciated and fostered (Hofstede \& Bond 1984).

Finally, regarding the power of $R \& D$ in the organization, we distinguish between $R \& D$ 's influence in its core domain —-the new-product development process—and R\&D's influence on internal company decisions. We specify influence on new-product development as R\&D’s potential to determine goals, procedures, and product features in innovation processes. We conceptualize influence on internal budgeting decisions as R\&D’s potential to affect intraorganizational budget and resource allocation decisions. In what follows, we draw on our conceptual framework to develop our hypotheses. 


\section{FIGURE 2 - Contingency Account of R\&D-Sales versus R\&D-Marketing Cooperation: Conceptual} Framework

Mean value of market-side response and technical-side responsea

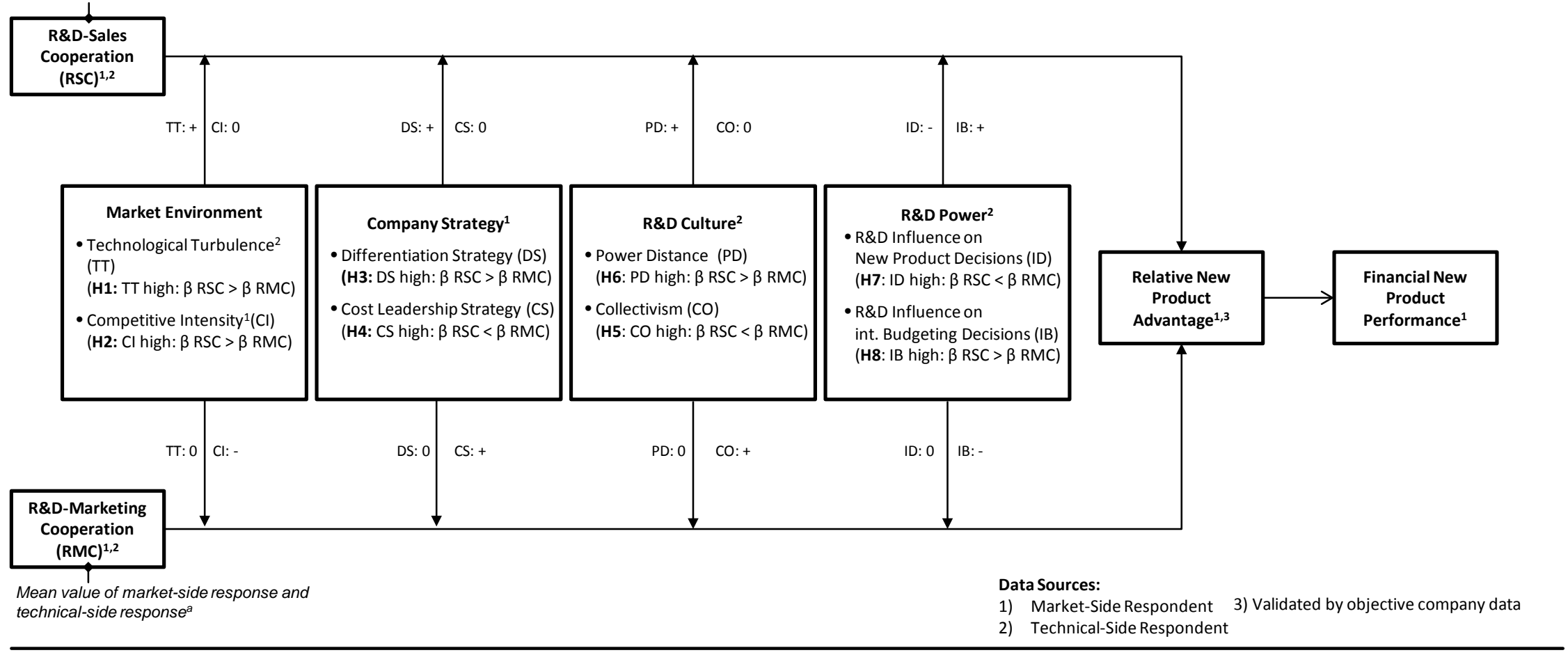

Notes. The hypotheses (H1-H8) refer to the simple slopes of RSC/RMC at high values of the moderators (Mean $+1 *$ standard deviation). RSC = R\&D-sales cooperation; RMC = R\&D-marketing cooperation; we do not derive a hypothesis on the relative new-product $\rightarrow$ financial new-product performance effect as it is established by prior research (Song $\&$

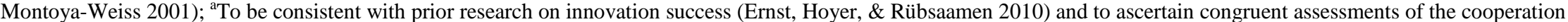
types, we verified interrater reliability of the market-side and technical-side responses and subsequently aggregated the measurements. 


\section{Hypotheses development}

We discuss our predictions regarding the moderating effects on the relationship between R\&D-marketing and R\&D-sales cooperation on relative new-product advantage in the following order: (1) market environment factors, (2) company strategies, and (3) R\&D culture and power.

\subsection{The moderating influence of market environment factors}

The resource-based view proposes that in forming a cooperation, the function holding the resources most suited to effective task fulfillment should be selected (Olson, Walker, \& Ruekert 1995). Therefore, in new-product development, in markets characterized by high technological turbulence R\&D should cooperate with the department that can provide superior information on technological developments in the industry. Drawing from the thought-world concept, we delineate differences between marketing and sales in terms of orientations and knowledge bases. On the basis of these thought-world differences, we argue that if technological turbulence is pronounced, R\&D-sales cooperation is more beneficial to relative new-product advantage than R\&D-marketing cooperation.

As a firm's boundary-spanning function and the "face of the company to the customer," sales undoubtedly has the closest contact with customers and competitors (Kotler, Rackham, \& Krishnaswamy 2006). In line with the thought-world concept, this configuration of sales tasks and responsibilities directly shapes sales' knowledge funds. Owing to its close contact to customers and competitors, sales should generally have more up-to-date and accurate market knowledge than marketing (Joshi 2010): "Sales has higher levels of specific market knowledge (i.e. about customers and competitors) than marketing” (Ernst, Hoyer, \& Rübsaamen (2010, p. 82). As market knowledge about customers and competitors represents a key dimension of a 
market orientation (Narver \& Slater 1990), we expect salespeople to be more market-oriented than employees of the marketing department.

Several research streams share the notion that the sales force constitutes firms' primary source of market information on customer needs, product features, and competitors' products. In this vein, literature investigating the marketing-sales interface proposes that sales is endowed with higher levels of knowledge about customer needs and the product features customers demand (Homburg \& Jensen 2007; Rouziès et al. 2005; Cespedes 1996). In addition, research on companies' information processing argues that salespeople are critical for generating firms’ market information (Le Bon \& Merunka 2006; Hughes, Le Bon, \& Rapp 2013; Ahearne et al. 2013). Explicating this notion, Hughes, Le Bon, \& Rapp (2013, p. 91) state that "the sales force may be a company's single best internal source of market, customer, and competitor information due to its frequent contact with customers, vendors, and other individuals present in the supply chain.”

Further elaborating on the knowledge-related differences between marketing and sales, the different task environment of the two departments promotes distinct thought worlds in terms of technical product-related knowledge. This proposition is in accordance with the notion of the salesperson as a knowledge broker (Verbeke, Dietz, \& Verwaal 2011), as a critical task of salespeople is to explain the firm's offering to the customer. That is, a core constituent of the selling task is that salespeople are able to communicate technical product features and product advantages and disadvantages. Additionally, sales is involved in solving customers' immediate problems with products (Homburg \& Jensen 2007). These tasks require salespeople to have high levels of technical knowledge. That is, the sales function “demands that salespeople acquire and possess knowledge about their products (at times the science behind their products), as well as 
about the way these products help their customers solve their problems” (Verbeke, Dietz, \& Verwaal 2011, p. 422). Consequently, to meet their key responsibility to explain the product to the customer and be able to sell successfully, salespeople have to deal with product features in detail. Owing to this strong focus on product specifications and how these fit with customers' technical demands, sales should have higher levels of technical knowledge than marketing. Figuratively, salespeople are "attuned to which product features will fly and which will die" (Kotler, Rackham, \& Krishnaswamy 2006, p. 3). Despite salespeople’s closeness to customers and their resulting high levels of knowledge, marketing’s long-horizon view (Homburg \& Jensen 2007) might suggest the effectiveness of promoting R\&D-marketing cooperation in an environment with high technological turbulence. However, while marketing’s long-term orientation may represent a valuable strategic input to the innovation process, the counterargument may be that in a turbulent, highly dynamic environment, short-term guidance and information are required. In this respect, prior research firmly underlines that particularly in dynamic environments, immediate organizational adaptiveness and responsiveness to external requirements represent core capabilities for innovation success (Calantone, Garcia, \& Dröge 2003; Hurley \& Hult 1998; Han, Kim, \& Srivastava 1998). Thus, leveraging sales’ up-to-date market knowledge in new-product development may be especially beneficial in dynamic environments that require high firm responsiveness.

In sum, because of their boundary-spanning function and close contact to customers, salespeople routinely receive a steady flow of in-depth information about developments in the market. Therefore, since compared to marketing sales should have higher levels of up-to-date knowledge of customers' needs as well as higher levels of technical knowledge, we hypothesize:

Hypothesis 1. If technological turbulence is high, R\&D-sales cooperation has a more positive effect on relative new-product advantage than R\&D-marketing cooperation. 
If competitive intensity is high, a critical goal of firms' new-product development is to create a product that matches or exceeds the value provided by competitive products (Homburg, Workman, \& Krohmer 1999). To this effect, R\&D requires extensive information on competitive offers currently sold in the market. Further, beyond existing competitive offers, intelligence on prospective products of competitors is critical to counter these developments. In recognition of the strong information needs of $R \& D$ if competitive intensity is high, on the basis of the resource-based view R\&D should cooperate with the department that can provide superior information on competitors' product innovations.

The thought-world concept suggests that the type of information a department holds depends on its core tasks and responsibilities (Homburg \& Jensen 2007). As the firm’s boundary-spanning function, sales is strongly connected in the market and has close customer relationships. Salespeople might leverage these network relationships to find out about “competitor’s projects, learn about new product launches before they take place, [and] discover new products in test market areas” (Le Bon \& Merunka 2006, p. 396). The boundary-spanning position allows sales to harvest more accurate, relevant, and up-to-date knowledge about competitors than marketing, which has no direct customer contact: "although multiple sources for attaining competitive intelligence exist, the richest source of [competitive intelligence] comes from salespeople, because they frequently interact with customers and competitive intelligence is an integral part of selling activities” (Ahearne et al. 2013, p. 37). Arguing that sales' specific knowledge about competitors and competitors' innovations is more sophisticated than marketing's competitive intelligence, we hypothesize:

Hypothesis 2. If competitive intensity is high, R\&D-sales cooperation has a more positive effect on relative new-product advantage than R\&D-marketing cooperation. 
3.2 The moderating influence of company strategy factors

\subsubsection{Differentiation strategy}

A company following a differentiation strategy strives to provide superior value to customers (Walkert \& Ruekert 1987), which results from fully addressing the customer's needs. Therefore, if a company follows a differentiation strategy focusing on value creation for the customer, $\mathrm{R} \& \mathrm{D}$ requires precise information on customer wishes. Beyond knowledge of customer needs, $\mathrm{R} \& \mathrm{D}$ requires information on the features of competitive offers to be able to differentiate the product from rivals and thus achieve a relative product advantage. Consequently, in companies that follow a differentiation strategy to achieve innovation success, R\&D must cooperate with the department that provides superior information on customer needs and competitors' offers. Because of its diverse linkages in the market, the sales department possesses higher levels of specific knowledge about customers and competitors than marketing (Ernst, Hoyer, \& Rübsaamen 2010). Hence, “the sales force may be a company’s single best internal source of market, customer, and competitor information due to its frequent contact with customers, vendors, and other individuals present in the supply chain” (Hughes, Le Bon, \& Rapp 2013, p. 91). Thus:

Hypothesis 3. If differentiation strategy is high, R\&D-sales cooperation has a more positive effect on relative new-product advantage than R\&D-marketing cooperation.

\subsubsection{Cost leadership strategy}

If a company follows a cost leadership strategy, its primary goal is to realize cost-saving potentials by rationalizing internal processes (Homburg, Workman, \& Krohmer 1999). With respect to new-product development, a company's cost leadership strategy is reflected in controlling costs for the new product and producing it in a cost-efficient manner (Engelen \& Brettel 2012). While a differentiation strategy is closely intertwined with customizing products 
for single customers (which is costly), limiting the costs in the innovation process entails the creation of relatively standardized products with a restricted product variety to avoid complexity costs. Given such standardized offerings, achieving relative new-product advantage critically depends on carefully identifying target customer segments and configuring the product with essential features that appeal to these target segments (Slater \& Olson 2000). In other words, successfully implementing a cost leadership strategy in new-product development requires a sophisticated strategic positioning analysis of the offering in the market. Hence, if a company follows a cost-based strategy, R\&D should cooperate with the department that is more proficient in positioning the offering strategically.

Salespeople are typically responsible for a set of customers in a sales territory or in a specific industry segment, while marketing managers are typically responsible for a specific product or brand offered by the firm (Rouziès et al. 2005). Prior research shows that these fundamentally different thought worlds lead to distinct task orientations: while sales exhibits higher levels of customer orientation, marketing shows higher levels of product orientation (Homburg \& Jensen 2007; Rouziès et al. 2005, Cespedes 1996). A product orientation indicates a focus on optimizing the product and developing product-related market strategies (Homburg \& Jensen 2007). As a result of marketing's focus on product optimization and positioning (Griffin \& Hauser 1996; Cespedes 1996), R\&D-marketing cooperation should be more beneficial to relative new-product advantage than $R \& D$-sales cooperation if the company follows a cost leadership strategy.

Further corroborating this argumentation, marketing generally assumes "broad strategic responsibilities” (Cespedes 1993, p. 37) for products and is often considered to be the strategy department: "Sales has a much stronger and more operational link to individual customers, while 
marketing has a more strategic focus on customer segments and the entire product business” (Ernst, Hoyer, \& Rübsaamen 2010, p. 82; see also Homburg, Workman, \& Krohmer 1999). Prior research indicates that salespeople might focus excessively on individual customers and therefore "fail to see the big picture” (Beverland et al. 2006, p. 391; see also Ernst, Hoyer, \& Rübsaamen 2010). Running contrary to the goals of a cost-based strategy, sales commonly reports information suggesting the addition of product features and the extension of product lines (Gordon et al. 1997; Judson et al. 2006). In sum, as market trend analysis, market segmentation, and product positioning constitute key marketing responsibilities (Griffin \& Hauser 1996), which are important prerequisites for new-product advantage under a cost leadership strategy, we suggest:

Hypothesis 4. If cost leadership strategy is high, R\&D-marketing cooperation has a more positive effect on relative new-product advantage than R\&D-sales cooperation.

\section{3 $R \& D$ culture, $R \& D$ power, and the role of interfunctional relationships}

H1-H4 are based on the notion that according to the resource-based view, R\&D should cooperate with the function that provides the most appropriate complementary resources for given circumstances. In addition, the resource-based view posits that R\&D should cooperate with the function with which resource exchange is more effective (Pfeffer \& Salanczik 1978). Drawing on this reasoning, we derive subsequent hypotheses (H5-H8) examining how R\&D culture and R\&D power influence the linkage between R\&D-sales/marketing cooperation and relative new-product advantage.

\subsection{The moderating influence of $R \& D$ culture}

Prior research suggests that besides an overarching national and corporate culture, discernible cultural distinctions also exist between functional subunits (Hofstede 2002; Cooke \& 
Rousseau 1988). In what follows, our argumentation builds on the notion that the task characteristics of sales and marketing exert an influence on the departments' subcultures beyond the influence of national culture. The effectiveness of resource exchange between departments depends on whether the departmental cultures fit to each other, particularly in terms of having similar working styles and communication patterns. Prior research shows that cultural misfits between departments lead to relationship conflict and reduce the quality of cooperation (Menon, Bharadwaj, \& Howell 1996).

\subsubsection{Collectivism}

The cultural value of collectivism refers to how individuals perceive social relationships and the extent to which individuals' cooperation in groups is appreciated (Hofstede \& Bond 1984). If a departmental culture is marked by high collectivism, department members focus on shared goals and value teamwork. We propose that if R\&D’s culture tends to be collectivist, R\&D should cooperate with marketing owing to a closer cultural fit, which facilitates resource exchange and eventually promotes a relative new-product advantage.

Two characteristic of marketing's task environment foster the likelihood that collectivist values are shared in the department. First, the task environment usually demands a significant portion of project-based work, such as the creation of advertising campaigns or preparation of an annual marketing plan (Cespedes 1996; Rouziès et al. 2005). The project-based nature of most marketing tasks promotes the occurrence of teamwork, rendering it an integral part of marketing activities and nurturing collectivist values (Griffin \& Hauser 1996). Second, marketing is typically organized around brands and products, focusing project teams on collectively shared brand- or product-related goals, such as market-share objectives for a brand (Ernst, Hoyer, \& Rübsaamen 2010). In contrast, research suggests that salespeople tend to hold individualistic 
values (Weitz \& Bradford 1999). As salespeople commonly receive personal goals and incentives, they focus strongly on their individual achievement, and as a result salespeople's collectivist orientation should be rather low. Therefore, if R\&D's culture reflects high collectivism, to achieve a relatively closer cultural fit R\&D should cooperate with marketing to enhance relative new-product advantage. Thus:

Hypothesis 5. If R\&D collectivism is high, R\&D-marketing cooperation has a more positive effect on relative new-product advantage than R\&D-sales cooperation.

\subsubsection{Power distance}

The cultural dimension of power distance refers to department members’ perception of hierarchical, formalized power structures among employees and superiors (Hofstede \& Bond 1984). If power distance is pronounced within a function, hierarchies among department members are perceived as normal and relationships between employees and superiors tend to be formalized and strictly hierarchical. We predict that if R\&D culture is characterized by high power distance, $R \& D$ should collaborate with sales to promote relative new-product advantage. Our reasoning rests on the notion that in the case of high R\&D power distance, the cultural fit of R\&D with the sales department is higher than with the marketing department, because the high level of formalized control and incentive systems in the sales department institutionalizes a departmental culture of high power distance.

In sales departments, formalized managerial control systems of salesperson performance and associated incentive systems tend to be omnipresent (Piercy, Cravens, \& Lane 2009; Geiger \& Guenzi 2011; Homburg, Jensen, \& Krohmer 2008). That is, “management control is a key dimension of running a sales organization” (Piercy, Cravens, \& Lane 2009, p. 459). Of all sales organizations in the US, 90\% employ individual control and incentive systems for their sales force (Dustin \& Belasen 2013). The prevalence of managerial control and incentive systems in 
the sales department increases the likelihood of a high power distance culture for two reasons. First, a core task of sales managers is controlling salespeople's performance, which sets the basis for salespeople’s compensation (Krafft 1999). Owing to their monitoring and controlling of salespeople’s performance, sales managers exert an enormous influence on salespeople’s compensation. This influence gives sales managers substantial power over their subordinate salespeople and establishes a rigid hierarchy fostering a culture of high power distance in sales departments. Importantly, target-setting and monitoring for salespeople on the sales team level instead of the individual level might encourage teamwork and induce a lower power distance in the sales department. However, to date, in 74\% of sales departments in many industrial contexts, individual salesperson control and incentive systems seem to prevail (Burke \& Cullen 2014).

Second, the strong prevalence of control and incentive systems relating to salesperson performance foster a culture of high power distance because they enable and establish hierarchies among salespeople in the department. Salesperson performance may be easily quantified (e.g., based on sales volume) and is often visibly communicated in a sales department (Krafft 1999). For instance, to foster competition among salespeople, sales managers regularly communicate monthly or even daily rankings of each individual salesperson's performance (Poujol, Fournier, \& Tanner 2011). Hence, salespeople are often familiar with performance levels of their colleagues, promoting the establishment of hierarchies in sales department (Ibarra \& Andrews 1993), again contributing to a departmental culture of high power distance in sales.

Conversely, in the marketing department power distance should be less marked than in sales, because managerial control and incentive systems that enhance power distance are considerably less prevalent (Cespedes 1996; Homburg, Jensen, \& Krohmer 2008) for three reasons. First, employee performance in marketing is considerably more difficult to quantify than 
in sales owing to the long-term focus and low measurability (Ernst, Hoyer, \& Rübsaamen 2010; Krafft 1999). For instance, for the marketing task of creating a strong brand image, payoffs may materialize in the distant future and be challenging to assess. Second, marketing's tasks often require a long-term strategic perspective (Cespedes 1996; Ernst, Hoyer, \& Rübsaamen 2010). A high level of short-term control and incentive systems would constitute an impediment to marketing's long-term focus: “Due to the incentives for salespeople and their results orientation, salespeople often tend to be more short-term-oriented than marketers” (Rouziès et al. 2009, p. 115). Third, marketing's tasks, such as creating brand equity or advertising and promotion material, often entail a high level of imagination (Andrews \& Smith 1996). In this respect, prior research shows that high control and incentive levels may impair employee inventiveness (Ariely et al. 2009). Consequently, as the extent of managerial control and incentive systems is lower in the marketing department, power distance tends to be less pronounced than in sales.

In sum, we suggest that owing to the higher prevalence of control and incentive systems in sales relative to marketing, the sales department's culture tends to exhibit higher levels of power distance. Hence, to promote cultural fit and cooperation quality, if R\&D’s culture is distinguished by high power distance, then to increase relative new-product advantage $\mathrm{R} \& \mathrm{D}$ should cooperate with the sales department rather than with marketing.

Hypothesis 6. If R\&D power distance is high, R\&D-sales cooperation has a more positive effect on relative new-product advantage than $R \& D-$ marketing cooperation.

\subsection{The moderating influence of $R \& D$ power}

\subsubsection{R\&D influence on new-product decisions}

The resource-based view suggests that $R \& D$ should cooperate with the department with which resource exchange is more effective. The effectiveness of the resource exchange between 
departments is influenced by the interfunctional power configuration (Homburg \& Jensen 2007). A power conflict might severely restrict the resource flow between the two functions and thus affect innovation success. Further, high levels of R\&D influence on new-product decisions could create power conflicts in the cooperation of R\&D with marketing as well as with sales. In that case, both R\&D-sales cooperation and R\&D-marketing cooperation might be unrelated to or even detrimental to relative new-product advantage.

However, while we suggest that for high R\&D new-product influence a power conflict between R\&D and sales may arise, for the marketing department this should not be the case. As we previously suggested, marketing tends to hold collectivist values and commonly engages in teamwork (Griffin \& Hauser 1996; Cespedes 1996). Consequently, the marketing department is considerably better equipped to cope with the power imbalance if $\mathrm{R} \& \mathrm{D}$ influence on newproduct decisions is high, and to maintain a sufficient level of cooperation quality. Hence, in this situation, the resource exchange among R\&D and marketing should be more effective. In this respect, resource exchange between $R \& D$ and marketing may be essentially facilitated by top management, which has been characterized as "the force that pulls different functional groups together” (Swink 2000, p. 211). Top management may support the formation of formalized, collective work forms such as permanent team structures, regular meetings, or job rotation programs that favor R\&D-marketing cooperation (Gupta, Raj, \& Wilemon 1986; Swink 2000). Moreover, by allocating resources and power to these formalized collective work structures, top management may create an environment conducive to teamwork that again promotes the effectiveness of R\&D-marketing cooperation (Swink 2000). In sum, if R\&D’s influence on newproduct decisions is strong, requiring team spirit to counter potential conflicts arising from power 
imbalances, R\&D-marketing cooperation may be more conducive to innovation success owing to marketing's familiarity with forms of collective work.

Hypothesis 7. If R\&D influence on new-product decisions is high, R\&D-marketing cooperation has a more positive effect on relative new-product advantage than R\&D-sales cooperation.

\subsubsection{R\&D influence on internal resource allocation}

A strong R\&D influence on resource allocation decisions is indicative of a technologyoriented firm that places emphasis on technological developments (Atuahene-Gima \& Evangelista 2000). In such a technology-centered organizational context, cooperation of R\&D with sales should be more conducive to relative new-product advantage. Owing to its key task of explaining products to customers, the sales force tends to hold considerably higher levels of technical knowledge than the marketing department (Homburg \& Jensen 2007; Rouziès et al. 2005; Cespedes 1996). In technology-oriented firms, the sales force’s market knowledge regarding technological trends may constitute a particularly critical input into the new-product development process. Consequently, if $\mathrm{R} \& \mathrm{D}$ influence on internal resource allocation decisions is high, reflecting a strong corporate emphasis on technology, owing to sales' technological competence R\&D-sales cooperation should be more beneficial for innovation success. Thus:

Hypothesis 8. If R\&D influence on internal resource allocation is high, R\&D-sales cooperation has a more positive effect on relative new-product advantage than R\&D-marketing cooperation.

\section{Methodology}

\subsection{Data collection and sample}

\subsubsection{Data collection procedure}

Empirical testing of our research model required data for variables such as R\&D-sales cooperation, environmental factors, and organizational factors. While these variables cannot be 
obtained through databases, senior executives involved in NPD projects can reasonably assess these constructs. Therefore, we relied on a key informant approach to test our hypotheses. We collected dyadic survey data from senior executives across multiple German business-to-business industries in which the issue of R\&D-marketing and sales cooperation in new-product development is of importance.

From a commercial list provider, we acquired a random sample of business-to-business manufacturing and technology firms that were likely to meet these criteria. Then, by screening data bases and corporate websites and through exploratory telephone calls, we identified firms that were suitable for testing our research questions. For 1,400 firms, we were able to identify a senior executive who had an overview of new-product development and our other variables of interest —in most cases the sales or marketing director. We contacted these executives by e-mail or telephone to solicit participation in the study. Depending on the respondent's preference, the survey questionnaire was administered via ordinary mail or e-mail, or in the form of an online questionnaire for which we set up a website with an entry code for each respondent.

\subsubsection{Selection of dyads and data sources}

When we asked respondents to take part, we emphasized that our research question needed the participation of two executives per firm to capture the view of both the market side and the technical side. We obtained dyadic responses from 230 firms for a response rate of 16\%, which compares favorably to prior multi-informant studies in the marketing literature (e.g., Homburg, Artz, \& Wieseke 2012). Each dyad included one respondent from the market side (e.g., head of sales, head of marketing) and one respondent from the technical side (e.g., head of R\&D, technical director). In the data analyses, we employ variables provided by both the market side (relative new-product advantage, competitive intensity, company strategies) and the 
technical side (technological turbulence, R\&D culture/power), and for R\&D-sales and R\&Dmarketing cooperation we use the aggregated responses of the market and technical sides. Importantly, relying on a key informant approach in line with prior research (e.g., Homburg \& Jensen 2007), we do not differentiate in our data analyses between key respondents on the market side, such as sales and marketing managers, and those on the technical side between, for example, heads of R\&D and technical directors.

We collected dyadic data for two reasons. First, some of our constructs can be better assessed by informants who are closer to the market (e.g., competitive intensity) while others can be better assessed by informants who have a technical background (e.g., technological turbulence). Second, assessment of different constructs by different people limits the likelihood of common method bias (Podsakoff et al. 2003).

Two tests controlled for potential nonresponse bias. First, we compared the distribution of the responding firms in terms of firm size and industry affiliation with that of the original population (Rogelberg \& Stanton 2007). Results of $\chi^{2}$ tests showed no significant differences between our sample and the original population. Second, comparison of the latest and earliest thirds of responses showed significant differences in scale means $(p<.05)$ for only one of 11 constructs, indicating that nonresponse bias should not be a major issue with our data (Armstrong \& Overton 1977). Respondents’ average job experience is 20.5 years (SD = 7.7) for respondents on the market side and 20.9 years $(S D=7.8)$ for respondents on the technical side. Table 1 provides an overview of our sample. 
TABLE 1 - Sample Composition and Respondent Job Titles

\begin{tabular}{|c|c|c|c|c|c|c|c|}
\hline Industry & $\%$ & Firm Size $^{a}$ & $\%$ & $\begin{array}{l}\text { Market-side } \\
\text { Respondent }\end{array}$ & $\%$ & $\begin{array}{l}\text { Technical-side } \\
\text { Respondent }\end{array}$ & $\%$ \\
\hline $\begin{array}{l}\text { Mechanical } \\
\text { engineering }\end{array}$ & 23.0 & $<200$ & 37.0 & Head of sales & 64.3 & Head of R\&D & 61.3 \\
\hline Machine tools & 14.3 & 200 to 499 & 35.2 & Head of marketing & 14.8 & Technical director & 17.0 \\
\hline Electronics & 10.5 & 500 to 999 & 17.4 & Managing director & 8.3 & Managing director & 7.4 \\
\hline Automotive & 10.0 & $\begin{array}{c}1,000 \text { to } \\
4,999\end{array}$ & 8.7 & $\begin{array}{l}\text { Head of key account } \\
\text { management }\end{array}$ & 5.2 & $\begin{array}{l}\text { Head of product } \\
\text { management }\end{array}$ & 3.9 \\
\hline $\begin{array}{l}\text { Synthetic } \\
\text { materials }\end{array}$ & 8.7 & $\geq 5,000$ & 1.7 & Other & 7.4 & $\begin{array}{l}\text { Head of innovation } \\
\text { management }\end{array}$ & 2.2 \\
\hline $\begin{array}{l}\text { Medical } \\
\text { equipment }\end{array}$ & 4.8 & & & & & $\begin{array}{l}\text { Head of application } \\
\text { engineering }\end{array}$ & 2.2 \\
\hline $\begin{array}{l}\text { Automation \& } \\
\text { robotics }\end{array}$ & 4.3 & & & & & Other & 6.0 \\
\hline Software & 3.9 & & & & & & \\
\hline Textile industry & 3.1 & & & & & & \\
\hline Other & 17.4 & & & & & & \\
\hline
\end{tabular}

Note: Sample based on $n=230$ firms. ${ }^{\mathrm{a}}$ Number of employees

\subsection{Construct measurement, reliability diagnostics, and measurement validations}

Our study relied on existing scales drawn from prior studies. In the Appendix, we provide detailed information on all scales of the study, and Table 2 reports an intercorrelation matrix and descriptive statistics.

\subsubsection{Measurement of $R \& D$-sales/marketing cooperation}

As our key independent variables, R\&D-sales cooperation and R\&D-marketing cooperation were rated by the respondent from the market side as well as from the technical side. To calculate the variables employed in the data analysis, we aggregated the market-side and technical-side responses (Ernst, Hoyer, \& Rübsaamen 2010). That is, for R\&D-sales cooperation of one firm we used the mean value of $R \& D$-sales cooperation rated by the respective marketside respondent and R\&D-sales cooperation rated by the respective technical-side respondent. 
This approach implies that on the market side both cooperation variables are rated by either a sales manager or a marketing manager. Prior research has demonstrated that this approach is feasible and that sales and marketing managers accurately assess variables related to their own and the other department. In this respect, effects of a cross-functional cooperation model do not vary for sales or marketing managers, implying that both provide accurate assessments (Homburg \& Jensen 2007).

To ensure the reliability of the aggregated measures and show that aggregation of the market-side and technical-side respondents for R\&D-sales and R\&D-marketing cooperation is justified, we calculated median within-group agreement $\left(\mathrm{r}_{\mathrm{wg}}\right)$, which is frequently used to validate data aggregation (Ernst, Hoyer, \& Rübsaamen 2010; Bliese 2000; James, Demaree, \& Wolf 1984). Our data show high median within-group agreement for R\&D-sales cooperation $\left(\mathrm{r}_{\mathrm{wg}}=.88\right)$ and $\mathrm{R} \& \mathrm{D}-$ marketing cooperation $\left(\mathrm{r}_{\mathrm{wg}}=.91\right)$, indicating that aggregation is justified.

\subsubsection{Reliability diagnostics}

To assess the psychometric quality of our data, we computed Cronbach’s alpha and composite reliability for all reflective scales and found values ranging between 0.70 and 0.94 . All scales exceeded the threshold values proposed in the literature (Bagozzi \& Yi 1988; Nunnally 1978). Average variance extracted estimates of equal to or greater than 0.50 for all constructs affirm convergent validity of our scales (Bagozzi \& Yi 1988). We also tested discriminant validity against the criterion proposed by Fornell and Larcker (1981), which requires that the average variance extracted from each factor exceed the squared correlations between this factor and all other constructs. All constructs passed this test.

\subsubsection{Validation of relative new-product advantage with objective company data}


To assess external validity of the relative new-product advantage measure, we tested whether the variable is positively associated with companies' realized profit. For a subsample of 82 companies (36\% of the sample), we were able to match survey responses with the respective company profit, which we obtained from a database of a commercial provider for business information (Bisnode). The zero-order correlation between the relative new-product advantage measure and corporate profit is positive and significant $(\mathrm{r}=.30, p<.01)$. When corporate profit is regressed on relative new-product advantage while controlling for industry affiliation and company size, the effect of the relative new-product advantage variable remains positive and significant $(\beta=.21, p<.05)$. These results indicate that the relative new-product advantage measurement exhibits external validity.

\subsubsection{Validation of relative new-product advantage with financial new-product performance}

Additionally, we included financial new-product performance (provided by the market-side respondent) in the estimation of the moderated regression as an outcome of relative new-product advantage. We calculated a moderated mediation model to assess whether the indirect effects of R\&D-sales and R\&D-marketing cooperation indeed transfer to financial new-product performance via relative new-product advantage. Results of this analysis are displayed in Web Appendix W2 and illustrate that relative new-product advantage constitutes a key mediator between R\&D-sales/marketing cooperation and financial new-product performance.

\subsection{Model estimation}

\subsubsection{Analytical approach}

To estimate our empirical model, we employed moderated multivariate regression analysis with an ordinary least squares estimator (Aiken \& West 1991). Model estimation relied on a twostep approach. First, we estimated two baseline models, a full model including all hypothesized 
interactions and eventually we replicated the full model without controls to establish its robustness. Prior to the model estimation, we centered all independent variables on their mean and we formed the interaction terms by multiplying the mean-centered predictor and the meancentered moderator (Aiken \& West 1991). In the second step, for the hypotheses testing we drew on the results of the full model to conduct a simple slope analysis. A simple slope analysis tests the significance of a predictor's main effect on a dependent variable at a specific value of the respective moderator. Applying the simple slope analysis to our research question, we compared the main effects of R\&D-sales cooperation and R\&D-marketing cooperation on relative newproduct advantage, reflecting our hypotheses, at high values of the hypothesized moderators and tested their significance. For example, we compared the main effects of R\&D-sales and R\&Dmarketing cooperation on relative new-product advantage if technological turbulence is high. In this respect, "high" refers to one standard deviation above the variable's mean value and "low" refers to one standard deviation below the mean value. For all models estimated, inspection of variance inflation factors and condition indices indicates no substantial degree of multicollinearity (Kleinbaum et al. 1998). Table 3 provides the full results of the moderated regression estimations and Table 4 shows results of the simple slope analysis. In Table 3 and Table 4, we report standardized regression coefficients (denoted as $\beta$ ), which are calculated as follows: $\beta=b *$ SD of predictor/SD of dependent variable; $b=$ unstandardized regression coefficient, SD = standard deviation. 
TABLE 2 - Intercorrelations, Descriptive Statistics, and Reliabilities

\begin{tabular}{|c|c|c|c|c|c|c|c|c|c|c|c|c|c|c|c|c|}
\hline & & 1 & 2 & 3 & 4 & 5 & 6 & 7 & 8 & 9 & 10 & 11 & 12 & 13 & 14 & 15 \\
\hline 1. & R\&D-sales cooperation & - & & & & & & & & & & & & & & \\
\hline 2. & $\begin{array}{l}\text { R\&D-marketing } \\
\text { cooperation }\end{array}$ & .15 & - & & & & & & & & & & & & & \\
\hline 3. & $\begin{array}{l}\text { Relative new-product } \\
\text { advantage }\end{array}$ & .27 & .17 & - & & & & & & & & & & & & \\
\hline 4. & Competitive intensity & -.09 & -.09 & -.08 & - & & & & & & & & & & & \\
\hline 5. & $\begin{array}{l}\text { Technological } \\
\text { turbulence }\end{array}$ & .03 & .11 & -.01 & .01 & - & & & & & & & & & & \\
\hline 6. & Differentiation strategy & .14 & .23 & .42 & -.18 & .07 & - & & & & & & & & & \\
\hline 7. & Cost leadership strategy & .12 & .22 & .13 & .09 & .04 & .23 & - & & & & & & & & \\
\hline 8. & $\mathrm{R} \& \mathrm{D}$ power distance & -.07 & -.10 & -.05 & -.01 & -.11 & -.08 & -.12 & - & & & & & & & \\
\hline 9. & R\&D collectivism & .10 & .12 & .08 & -.01 & .23 & .10 & .04 & -.29 & - & & & & & & \\
\hline 10. & $\begin{array}{l}\text { R\&D influence on new- } \\
\text { product decisions }\end{array}$ & -.11 & -.16 & -.04 & .03 & .06 & -.12 & -.04 & -.19 & .09 & - & & & & & \\
\hline 11. & $\begin{array}{l}\text { R\&D influence on } \\
\text { internal budgeting } \\
\text { decisions }\end{array}$ & .04 & .08 & .08 & -.07 & .02 & .12 & .08 & -.12 & .18 & .30 & - & & & & \\
\hline 12. & $\begin{array}{l}\text { Top management } \\
\text { support }\end{array}$ & .22 & .07 & .27 & .03 & .09 & .21 & .06 & -.11 & .28 & .04 & .07 & - & & & \\
\hline 13. & Size & -.14 & .24 & -.13 & -.01 & .10 & -.02 & .15 & -.03 & .09 & .02 & .13 & -.11 & - & & \\
\hline 14. & Product customization & .35 & -.06 & .13 & -.03 & .01 & .09 & -.01 & -.09 & .02 & .01 & -.04 & .02 & -.09 & - & \\
\hline 15. & $\begin{array}{l}\text { Financial new-product } \\
\text { performance }\end{array}$ & .16 & .15 & .19 & .00 & .23 & .16 & .00 & -.07 & .22 & .02 & .11 & .07 & .11 & -.02 & - \\
\hline & Means & 4.10 & 3.47 & 5.11 & 5.16 & 4.31 & 5.76 & 5.08 & 2.41 & 5.22 & 52.53 & 23.32 & 5.37 & 5.72 & 5.20 & 4.89 \\
\hline & Standard deviation & 1.14 & 1.69 & 1.05 & .99 & 1.10 & .94 & 1.11 & 1.01 & 1.24 & 19.03 & 18.95 & 1.07 & 1.16 & 1.51 & 1.32 \\
\hline & Cronbach's alpha & .92 & .94 & .79 & .84 & .82 & .77 & .71 & .70 & .86 & .79 & .80 & .78 & - & .87 & .93 \\
\hline
\end{tabular}

Note: Sample based on $n=230$ firms. Absolute values of correlation coefficients above .13 (.17) are significant at a 5\% (1\%) level. 
TABLE 3 - Results of the Moderated Regression Analysis

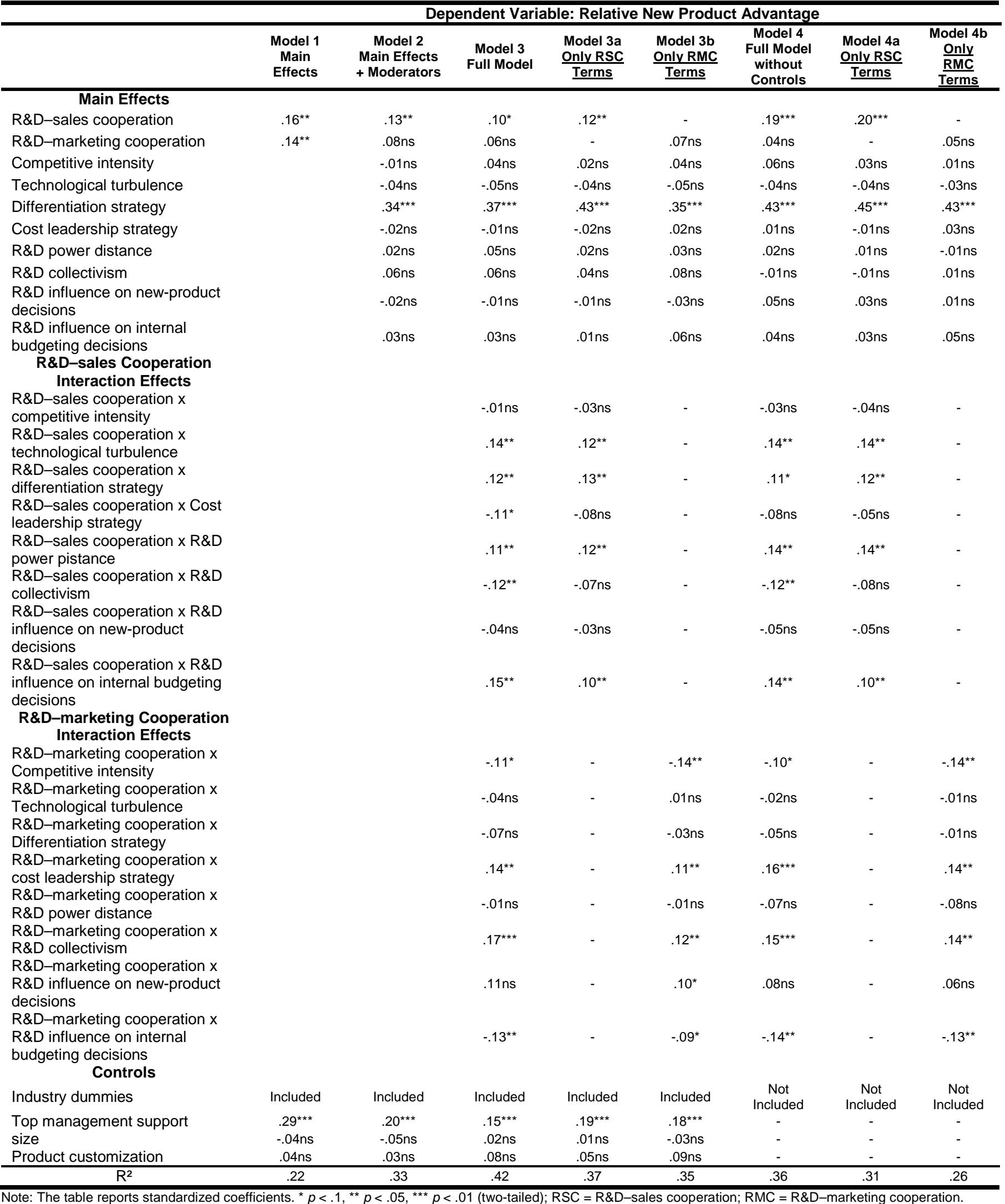




\subsubsection{Hypotheses testing}

Results of the moderated regression estimation and simple slope analysis corroborate our hypotheses that the relative effectiveness of R\&D-marketing cooperation versus $R \& D$-sales cooperation is contingent on market, company strategy, and R\&D factors. In the following, we discuss the findings for the individual hypotheses in detail.

In $\mathrm{H} 1$, we proposed that $\mathrm{R} \& \mathrm{D}$-sales cooperation has a more positive effect on relative new-product advantage than R\&D-marketing cooperation if technological turbulence is high. The interaction effect between R\&D-sales cooperation and technological turbulence is positive and significant $(\beta=.14, p<.05)$ whereas the interactive effect with $R \& D$-marketing cooperation is insignificant ( $\beta=-.04$, ns). Derived from these interactive effects, for high values of technological turbulence (mean value $+1 *$ standard deviation) the simple slope for $\mathrm{R} \& \mathrm{D}-\mathrm{sales}$ cooperation is $\beta_{\mathrm{RSC}}=.23(p<.05)$ and for $\mathrm{R} \& \mathrm{D}-$ marketing cooperation is $\beta_{\mathrm{RMC}}=.03(\mathrm{~ns})$. Since $\beta_{\mathrm{RSC}}$ is significantly higher than $\beta_{\mathrm{RMC}}(\Delta=.20, p<.05)$, R\&D-sales cooperation has a more positive effect on relative new-product advantage than R\&D-marketing cooperation if technological turbulence is present, which supports H1.

For H2, we suggest that R\&D-sales cooperation has a more positive effect on relative newproduct advantage than R\&D-marketing under high competitive intensity. The simple slope under this condition for R\&D-sales cooperation is $\beta_{\mathrm{RSC}}=.10(p<.10)$ and for R\&D-marketing cooperation is $\beta_{\mathrm{RMC}}=-.04$ (ns). Although $\beta_{\mathrm{RSC}}$ is higher than $\beta_{\mathrm{RMC}}$ the difference between both simple slopes is insignificant $(\Delta=.14, p>.1$ ), providing no support for $\mathrm{H} 2$.

In H3, we predicted that if the company follows a differentiation strategy, R\&D-sales cooperation has a more positive effect on relative new-product advantage than R\&D-marketing cooperation. Results support this proposition, as the simple slope of R\&D-sales cooperation 
significantly exceeds the simple slope of R\&D-marketing cooperation for high levels of differentiation strategy $\left(\beta_{\mathrm{RSC}}=.23, p<.01 ; \beta_{\mathrm{RMC}}=-.01\right.$, ns; $\left.\Delta_{\mathrm{RSC} / \mathrm{RMC}}=.24, p<.05\right)$. Similarly, we find support for $\mathrm{H} 4$, in which we expected that R\&D-marketing cooperation compared to R\&D-sales cooperation is more important to relative new-product advantage if the company focuses on a cost leadership strategy. In this condition, the simple slope of R\&D-marketing cooperation significantly exceeds the simple slope for $\mathrm{R} \& \mathrm{D}-$ sales cooperation $\left(\beta_{\mathrm{RMC}}=.21, p<\right.$ $\left..05 ; \beta_{\mathrm{RSC}}=-.01, \mathrm{~ns} ; \Delta_{\mathrm{RSC} / \mathrm{RMC}}=.22, p<.05\right)$.

Regarding moderating effects of R\&D characteristics, H5 predicts that if R\&D's culture is characterized by high levels of collectivism, R\&D-marketing cooperation is more effective. As the simple slope for R\&D-marketing cooperation at high values of R\&D collectivism significantly exceeds the R\&D-sales cooperation simple slope, we find support for H5 ( $\beta_{\mathrm{RSC}}=$ $\left..01, \mathrm{~ns} ; \beta_{\mathrm{RMC}}=.22, p<.01 ; \Delta_{\mathrm{RSC} / \mathrm{RMC}}=.23, p<.01\right)$. Conversely, in H6 we argue that if R\&D power distance is high, $\mathrm{R} \& \mathrm{D}-$ sales cooperation should be more beneficial to relative newproduct advantage than R\&D-marketing cooperation. Lending partial support to H6, if power distance is high in the $R \& D$ department, the simple slope of $R \& D-s a l e s$ cooperation exceeds the simple slope of R\&D-marketing cooperation $\left(\beta_{\mathrm{RSC}}=.21, p<.01 ; \beta_{\mathrm{RMC}}=.05\right.$, ns; $\Delta_{\mathrm{RSC} / \mathrm{RMC}}=.16$, $p<.10$ ). However, at very high levels of R\&D power distance (mean $+2 \mathrm{SD}$ ), H6 is fully confirmed $\left(\beta_{\mathrm{RSC}}=.30, p<.01 ; \beta_{\mathrm{RMC}}=.04, \mathrm{~ns} ; \Delta_{\mathrm{RSC} / \mathrm{RMC}}=.26, p<.01\right)$.

In H7, we propose that high levels of R\&D influence on new-product decisions render R\&D-marketing cooperation more effective for relative new-product advantage than R\&D-sales cooperation. While indeed the simple slope of $\mathrm{R} \& \mathrm{D}$-marketing cooperation is enhanced and significant under this condition $\left(\beta_{\mathrm{RMC}}=.16, p<.05\right)$, it does not significantly exceed the simple slope of R\&D-sales cooperation ( $\beta_{\mathrm{RSC}}=.07$, ns; $\Delta_{\mathrm{RSC} / \mathrm{RMC}}=.09$, ns). However, at very high 
levels of R\&D power distance (mean $+2 \mathrm{SD})$, $\mathrm{H} 7$ is fully confirmed $\left(\beta_{\mathrm{RSC}}=.02\right.$, ns; $\beta_{\mathrm{RMC}}=.26$, $\left.p<.05 ; \Delta_{\mathrm{RSC} / \mathrm{RMC}}=.24, p<.05\right)$. Finally, results provide support for H8, which predicts that R\&D-sales cooperation has a stronger effect on relative new-product advantage than R\&Dmarketing cooperation if R\&D influence on internal budgeting decisions is high. At high levels of R\&D influence on budgeting decisions, the simple slope of R\&D-sales cooperation significantly exceeds the simple slope of R\&D-marketing cooperation, corroborating H8 ( $\beta_{\mathrm{RSC}}=$ $\left..23, p<.01 ; \beta_{\mathrm{RMC}}=-.07, \mathrm{~ns} ; \Delta_{\mathrm{RSC} / \mathrm{RMC}}=.30, p<.01\right)$.

In our model estimation, the main effects of the moderating factors as well as the control variables tended to be insignificant. While this result initially may be surprising, it supports the necessity of a contingency account in new-product development, which our theoretical background and prior research underline (see the meta-analysis of Troy, Hirunyawipada, \& Paswan 2008). That is, in the area innovation success, independent variables should not tend to exhibit unconditional main effects effects on new-product success, but should instead be contingent on contextual factors from the organization or market environment.

\subsection{Robustness checks}

We conducted several robustness checks to verify the rigor of our data analyses (see Web Appendix W1 for an overview). To assess whether our results are unduly influenced by outliers, we inspected Cook's D. If Cook's D is greater than 1 for an observation, the observation exerts a substantial influence on the findings (Cook \& Weisberg 1982). As for our results Cook’s D ranges from .00 to .14 with a mean of .008 , we conclude that outliers do not distort our results.

\subsubsection{Variance inflation factors}


We calculated variance inflation factors (VIFs) of our main Model 3 to assess whether multicollinearity constitutes an issue in our model estimation. The VIFs range from 1.19 to 1.63 , indicating that multicollinearity is not a serious issue in this model.

\subsubsection{Non-linearity assessment}

To explore non-linearity in our model, we examine whether R\&D-sales cooperation or R\&D-marketing cooperation exhibit quadratic or cubic effects on relative new-product advantage. Results of our analysis indicate that R\&D-sales cooperation and R\&D-marketing cooperation have a linear relationship with relative new-product advantage, as the non-linear terms are barely significant and the linear models exhibit a better fit the data (see Web Appendix W4).

\subsubsection{Alternative model specifications}

To assess the sensitivity of our results to changes in the model, for the key Models 3 and 4 we estimated each model with either the R\&D-sales cooperation or R\&D-marketing cooperation term only. Results of these additional estimations do not substantially deviate from the outcomes of the full Models 3 and 4, underlining the robustness of the findings (see Table 3).

\subsubsection{Model replication hold-out sample}

To conduct an additional robustness check for our model estimation, we assessed Models 1-4 in Table 3 on a hold-out sample. To this end, we drew a random sample of two-thirds of the original data set $(n=153)$. We employed this random sample to replicate Models $1-4$. Results show no substantial discrepancies between this validation and the original model estimation (see Web Appendix W5 for the results of the hold-out sample). 
TABLE 4 - Simple Slope Analysis: Contingent Main Effects of R\&D-Sales versus R\&D-Marketing Cooperation

\begin{tabular}{|c|c|c|c|c|c|c|c|}
\hline Moderator & Hypotheses & $\begin{array}{c}\text { Moderator } \\
\text { X } \\
\text { RSC }\end{array}$ & $\begin{array}{c}\text { Moderator } \\
\text { X } \\
\text { RMC }\end{array}$ & $\begin{array}{l}\text { Simple Slope for RSC at } \\
\text { High Values (Mean }+1 S D) \\
\text { of Moderator ( } \beta \text { RSC) }\end{array}$ & $\begin{array}{l}\text { Simple Slope for RMC at } \\
\text { High Values (Mean }+1 S D) \\
\text { of Moderator ( } \beta \text { RMC) }\end{array}$ & $\begin{array}{l}\text { Do RSC I RMC } \\
\text { slopes differ } \\
\text { significantly? }\end{array}$ & $\begin{array}{l}\text { Hypothesis } \\
\text { Test }\end{array}$ \\
\hline $\begin{array}{l}\text { H1: } \\
\text { Technological } \\
\text { turbulence }\end{array}$ & $\begin{array}{c}\text { If technological } \\
\text { turbulence is high }{ }^{\mathrm{a}} \text {, RSC } \\
\text { has a more positive effect } \\
\text { on RNPA than RMC. } \\
\boldsymbol{\beta} \text { RSC }>\boldsymbol{\beta} \text { RMC }\end{array}$ & $.14^{\star \star}$ & ns & $.23^{\star \star \star}$ & $.03 n s$ & $\begin{array}{c}\beta \mathrm{RSC}>\beta \mathrm{RMC} \\
\Delta=.20^{* \star}\end{array}$ & Confirmed \\
\hline $\begin{array}{c}\text { H2: } \\
\text { Competitive } \\
\text { intensity }\end{array}$ & $\begin{array}{c}\text { If competitive intensity is } \\
\text { high }^{\mathrm{a}} \text {, RSC has a more } \\
\text { positive effect on RNPA } \\
\text { than RMC. } \\
\boldsymbol{\beta} \text { RSC }>\boldsymbol{\beta} \text { RMC }\end{array}$ & ns & $-.11^{*}$ & $.10^{*}$ & $-.04 n s$ & $\begin{array}{c}\beta \mathrm{RSC}>\beta \mathrm{RMC} \\
\Delta=.14 \mathrm{~ns}\end{array}$ & $\begin{array}{l}\text { Not Confirmed } \\
\text { (Directionally } \\
\text { Consistent) }\end{array}$ \\
\hline $\begin{array}{l}\text { H3: } \\
\text { Differentiation } \\
\text { strategy }\end{array}$ & $\begin{array}{c}\text { If differentiation strategy } \\
\text { is high }{ }^{\mathrm{a}}, \mathrm{RSC} \text { has a more } \\
\text { positive effect on RNPA } \\
\text { than RMC. } \\
\boldsymbol{\beta} \text { RSC }>\boldsymbol{\beta} \text { RMC }\end{array}$ & $.12^{\star *}$ & ns & $.23^{\star \star \star}$ & $-.01 n s$ & $\begin{array}{c}\beta \mathrm{RSC}>\beta \mathrm{RMC} \\
\Delta=.24^{* *}\end{array}$ & Confirmed \\
\hline $\begin{array}{l}\text { H4: Cost } \\
\text { leadership } \\
\text { strategy }\end{array}$ & $\begin{array}{l}\text { If cost leadership strategy } \\
\text { is high }{ }^{\mathrm{a}} \text {, RMC has a more } \\
\text { positive effect on RNPA } \\
\text { than RSC. } \\
\boldsymbol{\beta} \text { RSC }<\boldsymbol{\beta} \text { RMC }\end{array}$ & $-.11^{*}$ & $.14^{\star \star}$ & $-.01 \mathrm{~ns}$ & $.21^{\star \star}$ & $\begin{array}{c}\beta \mathrm{RSC}<\beta \mathrm{RMC} \\
\Delta=.22^{* *}\end{array}$ & Confirmed \\
\hline $\begin{array}{c}\text { H5: R\&D } \\
\text { collectivism }\end{array}$ & $\begin{array}{c}\text { If R\&D collectivism is } \\
\text { high }^{\mathrm{a}}, \text { RMC has a more } \\
\text { positive effect on RNPA } \\
\text { than RSC. } \\
\boldsymbol{\beta} \text { RSC }<\boldsymbol{\beta} \text { RMC }\end{array}$ & $-.12^{\star \star}$ & $.17^{\star \star \star}$ & $-.01 \mathrm{~ns}$ & $.22^{\star \star \star}$ & $\begin{array}{c}\beta \mathrm{RSC}<\beta \mathrm{RMC} \\
\Delta=.23^{\star \star \star}\end{array}$ & Confirmed \\
\hline $\begin{array}{l}\text { H6: R\&D power } \\
\text { distance }\end{array}$ & $\begin{array}{l}\text { If power distance is high } \\
\text { RMC has a more positive } \\
\text { effect on RNPA than } \\
\text { RSC. } \\
\beta \text { RSC > } \boldsymbol{\beta} \text { RMC }\end{array}$ & $.11^{\star \star}$ & ns & $.21^{\star \star \star}$ & $.05 n s$ & $\begin{array}{c}\beta \mathrm{RSC}>\beta \mathrm{RMC} \\
\Delta=.16^{*}\end{array}$ & $\begin{array}{c}\text { Partially } \\
\text { Confirmed } \\
\text { (Fully } \\
\text { Confirmed at } \\
\text { Mean + 2SD) }\end{array}$ \\
\hline $\begin{array}{c}\text { H7: R\&D } \\
\text { Influence on } \\
\text { new-product } \\
\text { decisions }\end{array}$ & $\begin{array}{c}\text { If R\&D NPD influence is } \\
\text { high }^{\mathrm{a}}, \text { RMC has a more } \\
\text { positive effect on RNPA } \\
\text { than RSC. } \\
\boldsymbol{\beta} \text { RSC }<\boldsymbol{\beta} \text { RMC }\end{array}$ & ns & $.11 \mathrm{~ns}$ & $.07 n s$ & $.16^{\star \star}$ & $\begin{array}{c}\beta \mathrm{RSC}<\beta \mathrm{RMC} \\
\Delta=.09 \mathrm{~ns}\end{array}$ & $\begin{array}{r}\text { Not Confirmed } \\
\text { (Confirmed at } \\
\text { Mean + 2SD) }\end{array}$ \\
\hline $\begin{array}{l}\text { H8: R\&D } \\
\text { Influence on } \\
\text { internal } \\
\text { budgeting } \\
\text { decisions }\end{array}$ & $\begin{array}{l}\text { If R\&D budgeting } \\
\text { influence high }{ }^{\mathrm{a}}, \text { RSC has } \\
\text { a more positive effect on } \\
\text { RNPA than RMC. } \\
\beta \text { RSC }>\boldsymbol{\beta} \text { RMC }\end{array}$ & $.15^{\star \star}$ & $-.13^{\star \star}$ & $.23^{\star \star \star}$ & $-0.07 n s$ & $\begin{array}{c}\beta \mathrm{RSC}>\beta \mathrm{RMC} \\
\Delta=.30^{* * *}\end{array}$ & Confirmed \\
\hline
\end{tabular}

Note: The table reports standardized coefficients. * $p<.1$, ** $p<.05$, *** $p<.01$ (two-tailed). RNPA = relative new-product advantage, RSC $=$ R\&D-sales cooperation, RMC $=$ R\&D-marketing cooperation; NPD = new-product development; SD = standard deviation; $\Delta=$ absolute difference between RSC standardized regression coefficient and RMC

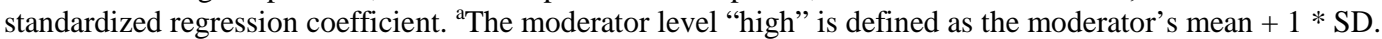




\section{Discussion}

\subsection{Summary of findings}

The primary goal of our study was to explore the potential contribution of the marketing and sales department to the new-product development process of industrial firms in different circumstances. Results of our study are largely in line with research postulating that organizational structure should fit company strategy and environment (Ginsberg \& Venkatraman 1985), confirming our conceptualization of a contingency account of R\&D-marketing/sales cooperation. We find that the relative effectiveness of both cooperation types depends on the velocity of the market environment, the firm’s strategic focus, and characteristics of the R\&D department. Specifically, we find that under conditions of high technological turbulence as well as a strong corporate focus on a differentiation strategy, R\&D-sales cooperation is robustly associated with relative new-product advantage. Conversely, if the company follows a cost leadership strategy or R\&D collectivism is high, $R \& D$-marketing cooperation is more conducive to relative new-product advantage. Moreover, we find tentative evidence that R\&D-marketing cooperation is more beneficial to innovation success than R\&D-sales cooperation if R\&D exerts a comparatively strong influence on new-product development decisions. Finally, we find that if R\&D possesses a high level of influence on internal resource allocation decisions, indicating a strong technology orientation of the firm (Atuahene-Gima \& Evangelista 2000), R\&D-sales cooperation is strongly associated with relative new-product advantage, as we argue that salespeople tend to hold more sophisticated technological product knowledge.

\subsection{Research issues}

Prior research on the incorporation of the "voice of the customer" in the new-product development process strongly focused on the R\&D-marketing interface, indicating that 
associating both functions has merits in terms of increasing relative new-product advantage (Troy, Hirunyawipada, \& Paswan 2008). However, until recently, academic work in this research stream did not distinguish between the role of marketing and that of the sales department in the innovation process. Seeing the changing role of sales in many companies and industries-in particular, the elevation of the sales department to an organizational actor of highest relevancedisentangling the roles of marketing and sales in new-product development is managerially and scientifically important. In this respect, several researchers have called for a more differentiated analysis of the marketing and sales functions (Ernst, Hoyer, \& Rübsaamen 2010). In response to these calls, with our study we aimed to provide a more fine-grained view on the effectiveness of R\&D-marketing and R\&D-sales cooperation under different contingency factors in the newproduct domain.

As the first to compare marketing and sales in the innovation process, Ernst, Hoyer, and Rübsaamen (2010) show that the direct effects of R\&D-marketing cooperation and R\&D-sales cooperation on relative new-product advantage vary in different stages of the innovation process. Our work contributes to this research by applying a contingency perspective to the differential effects of marketing and sales in the new-product domain. Introducing a contingency perspective to the analysis of R\&D-sales cooperation compared to R\&D-marketing cooperation may be conceptually important, as the effectiveness of R\&D-sales versus R\&D-marketing cooperation for innovation success strongly depends on specific market and company factors. Underlining this notion, Troy, Hirunyawipada, and Paswan (2008, p. 132) conclude from their meta-analysis that while "cross-functional cooperation may indeed have a direct impact on success, the combination of cooperation with other variables may be of greater importance” (see also Olson, Walker, \& Ruekert 1995). Comparing the effectiveness of R\&D-marketing and R\&D-sales 
cooperation across different market environments, company strategies, and R\&D factors, results reveal in part substantial differences between the contribution of marketing and sales to relative new-product advantage. With our study, we refine the assumption of Ernst, Hoyer, and Rübsaamen (2010) that sales might additionally support the innovation process supplementary to marketing's contribution. Our results suggest that in certain situations, for example if a company follows a differentiation strategy, sales does not make an additional, but necessary contribution, essential for the attainment of new-product success. These findings may be helpful to future work on the role of marketing and sales in product development, as we draw attention to the need to precisely account for the environmental and organizational circumstances under which R\&Dmarketing/sales cooperation is studied.

On the basis of the thought-world concept and the resource-based view, we suggest in our hypotheses development that the resources (e.g. knowledge and competences) that sales and marketing possess are shaped by their respective thought worlds. As the thought worlds of marketing and sales differ considerably (Homburg \& Jensen 2007), each department may hold a largely distinct set of resources. We propose that these different resource endowments of marketing and sales may be responsible for the differential effectiveness of R\&Dmarketing/sales cooperation in different market and organizational environments. However, we did not assess this conceptual explanation empirically. Therefore, a worthwhile avenue for future research in this domain may be to examine the specific mechanisms underlying the different effects of R\&D-marketing/sales cooperation under different contingencies. Specifically, prospective work might assess whether in fact divergent thought worlds of marketing and sales manifest in different knowledge bases and competencies, which in turn influence the effectiveness of R\&D-sales/marketing cooperation under different circumstances. 


\subsection{Managerial implications}

Our study provides potentially helpful implications to managerial practice. To achieve innovation success, sophisticated knowledge of customers' wishes and competitive offers undoubtedly needs to be included in new-product development. However, in light of the high costs associated with establishing cooperation among R\&D and other departments, the question arises as to whether R\&D-sales cooperation or R\&D-marketing cooperation is more instrumental in instilling the voice of the customer. For companies, our study indicates that careful evaluation of the department with which R\&D collaborates may be warranted, because the effectiveness of R\&D-sales versus R\&D-marketing cooperation for relative new-product advantage is subject to market factors, company strategy, and R\&D characteristics and, as such, might vary strongly.

Specifically, in highly dynamic market environments marked by high technological turbulence, companies may consider encouraging R\&D’s cooperation with the sales department. Since the boundary-spanning function sales is the organizational actor closest to the market and the individual customer, in these high-velocity environments sales is potentially positioned to provide sophisticated market knowledge to R\&D. Results of a simulation on the basis of our model estimation show that for very high levels of technological turbulence (two standard deviations above the mean level of technological turbulence; please refer to Table 5 for an overview of the simulation analysis), industrial firms relying on R\&D-sales cooperation gain a relative new-product advantage 17\% higher than firms that are not relying on R\&D-sales cooperation. Moreover, companies might foster R\&D-sales cooperation if they follow a differentiation strategy, as this strategy requires a profound understanding of customer needs and competitors' offerings. If firms strongly focus on a differentiation strategy (two standard 
deviations above the mean), our simulation reveals that firms relying on R\&D-sales cooperation exhibit a relative new-product advantage $18 \%$ higher than firms that are not relying on this cooperation type under these circumstances. Conversely, if a company pursues a cost leadership strategy, R\&D-marketing cooperation may be more conducive to relative new-product advantage. Results of a simulation on the basis of our model estimation show that for very high levels of cost leadership strategy (two standard deviations above the mean) industrial firms relying on $\mathrm{R} \& \mathrm{D}$-marketing cooperation gain a relative new-product advantage $12 \%$ higher than firms who are not relying on the latter in these circumstances.

Concerning R\&D characteristics, companies may consider fostering cooperation with R\&D that is characterized by high cultural fit and low friction owing to power imbalances. Our results tentatively show that companies might foster R\&D's cooperation with sales if R\&D's culture nurtures the value of power distance. In contrast, if R\&D’s culture is marked by high levels of collectivism, R\&D-marketing cooperation may be more beneficial to new-product advantage. Regarding R\&D power, firms could encourage R\&D-sales cooperation to increase relative new-product advantage if R\&D’s influence on internal budgeting decisions is high.

Generally, results of our study indicate that managers might account for the differences in marketing's and sales' thought worlds when deciding on cooperation partners for R\&D. To successfully promote relative new-product advantage, high-quality cooperation between the two departments is a key prerequisite. Since the potential cooperation quality with either marketing or sales might differ depending on department culture and power constellation, companies might screen marketing and sales regarding these factors to increase the effectiveness of the collaboration with R\&D. 
TABLE 5 - Simulation Analysis: Effects of R\&D-Sales/Marketing Cooperation on Relative New Product Advantage for High Moderator Values (Mean $+2 *$ SD)

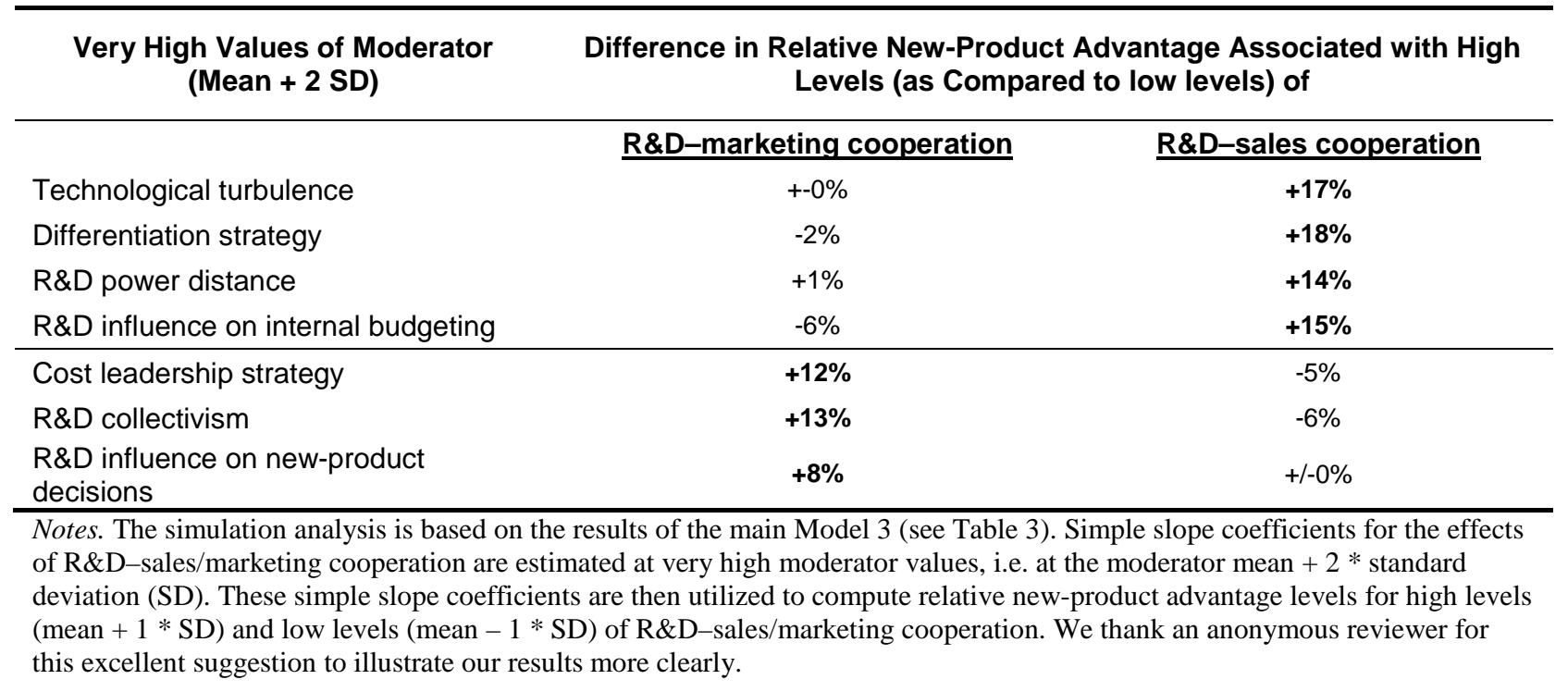




\section{References}

Ahearne, M., Lam, S. K., Hayati, B., \& Kraus, F. (2013). Intrafunctional Competitive Intelligence and Sales Performance: A Social Network Perspective. Journal of Marketing, 77, 37-56.

Aiken, L. S., \& West, S. G. West (1991). Multiple Regression: Testing and Interpreting Interactions. Sage Publications: Newbury Park, CA.

Andrews, J., \& Smith, D. C. (1996). In Search of the Marketing Imagination: Factors Affecting the Creativity of Marketing Programs for Mature Products. Journal of Marketing Research, 33 (2), 174-187.

Ariely, D., Gneezy, U., Loewenstein, G. \& Mazar, N. (2009). Large Stakes and Big Mistakes. Review of Economic Studies 76, 451-469.

Armstrong, J. S., \& Overton, T. S. (1977). Estimating Nonresponse Bias in Mail Surveys. Journal of Marketing Research, 14 (3), 396-402.

Atuahene-Gima, K. (1997). Adoption of New Products by the Sales Force: The Construct, Research Propositions, and Managerial Implications. Journal of Product Innovation Management, 14 (6), 498-514.

Atuahene-Gima, K., \& Evangelista, F. (2000). Cross-Functional Influence in New Product Development: An Exploratory Study of Marketing and Research and Development Perspectives. Management Science, 46 (10), 1269-1284.

Bagozzi, R. P. \& Yi, Y. (1988). On the Evaluation of Structural Equation Models. Journal of the Academy of Marketing Science, 16 (1), 74-94.

Beverland, M., Steel, M., \& Dapiran, G. P. (2006). Cultural Frames that Drive Sales and Marketing Apart: An Exploratory Study. Journal of Business \& Industrial Marketing, 21 (6), 386-394.

Bliese, P. D. (2000). Within-Group Agreement, Non-Independence, and Reliability: Implications for Data Aggregation and Analysis. Multilevel Theory, Research, and Methods in Organizations, Katherine J. Klein and Steve W. Kozlowski, eds. San Francisco: Jossey-Bass, 349-381.

Burke, R. \& Cullen, S. (2014). Trends in Sales Force Incentive Practice. HR Matters, 7, 16-19.

Calantone, R., Garcia, R., \& Dröge, C. (2003). The Effects of Environmental Turbulence on New Product Development Strategy Planning. Journal of Product Innovation Management, 20 (2), 90-103.

Cespedes, F. V. (1993). Coordinating Sales and Marketing in Consumer Goods Firms. Journal of Consumer Marketing, 10 (2), 37-55.

Cespedes, F. V. (1996). Beyond Teamwork: How the Wise Can Synchronize. Marketing Management, 5, 24-37.

Cooke, R.A., \& Rousseau, D.M. (1988). Behavioral norms and expectations: A quantitative approach to the assessment of organizational culture. Group and Organization Studies, 13, 245-273.

Cook, R. D. \& and Weisberg, S. (1982). Residuals and Influence in Regression. Chapman and Hall: New York. 
Dougherty, D. (1992). Interpretive Barriers to Successful Product Innovation in Large Firms. Organization Science, 3 (2), 179-202.

Dustin, S. \& Belasen, A.R. (2013). The Impact of Negative Compensation Shocks on Individual Sales Performance. Journal of Personal Selling \& Sales Management, 33 (4), 405-419.

Edgett, S., Shipley D. \& Forbes G. (1992). Japanese and British Companies Compared: Contributing Factors to Success and Failure in NPD. Journal of Product Innovation Management, 9 (1), 3-10.

Engelen, A., \& Brettel, M. (2012). A Coalitional Perspective on the Role of the R\&D Department within the Organization. Journal of Product Innovation Management, 29 (3), 489-505.

Ernst, H., Hoyer, W. D., \& Rübsaamen, C. (2010). Sales, Marketing, and Research-andDevelopment Cooperation across New Product Development Stages: Implications for Success. Journal of Marketing, 74 (5), 80-92.

Fornell, C., \& Larcker, D. F. (1981). Evaluating Structural Equation Models with Unobservable Variables and Measurement Error. Journal of Marketing Research, 18 (1), 39-50.

Geiger S. \& Guenzi P. (2011). Sales Management: A Multinational Perspective. Palgrave Macmillan, London.

Ginsberg, A., \& Venkatraman, N. (1985). Contingency Perspectives of Organizational Strategy: A Critical Review of the Empirical Research. Academy of Management Review, 10 (3), 421434.

Gordon, G. L., Schoenbachler, D. D., Kaminski, P. F., \& Brouchous, K. (1997). New Product Development: Using the Salesforce to Identify Opportunities. Journal of Business \& Industrial Marketing, 12 (1), 33-50.

Griffin, A., \& Hauser, J. R. (1996). Integrating R\&D and Marketing: A Review and Analysis of the Literature. Journal of Product Innovation Management, 13 (3), 191-215.

Gupta, A. K., Raj, S. P., \& Wilemon, D. (1986). A Model for Studying R\&D. Marketing Interface in the Product Innovation Process. Journal of Marketing, 50 (2), 7-17.

Harmancioglu, N., Droge, C., \& Calantone, R. J. (2009). Strategic Fit to Resources versus NPD execution proficiencies: what are their roles in determining success? Journal of the Academy of Marketing Science, 37 (3), 266-282.

Han, J. K., Kim, N., \& Srivastava, R. K. (1998). Market Orientation and Organizational Performance: Is Innovation a Missing Link?. Journal of Marketing, 62 (4), 30-45.

Hofstede, G., \& Bond, M. H. (1984). Hofstede's Culture Dimensions: An Independent Validation Using Rokeach's Value Survey. Journal of Cross-Cultural Psychology, 15, 417-433.

Homburg, C., \& Jensen, O. (2007). The Thought Worlds of Marketing and Sales: Which Difference Makes a Difference? Journal of Marketing, 71 (3), 124-142.

Homburg C., Jensen O., \& Krohmer H. (2008). Configurations of Marketing and Sales: A Taxonomy. Journal of Marketing, 72 (2), 133-154.

Homburg, C., Workman Jr, J. P., \& Krohmer, H. (1999). Marketing's Influence within the Firm. Journal of Marketing (1999), 1-17.

Homburg, C., Artz, M., \& Wieseke, J. (2012). Marketing Performance Measurement Systems: Does Comprehensiveness Really Improve Performance? Journal of Marketing, 76 (3), 56-77. 
Hughes, D. E., Le Bon, J., \& Rapp, A. (2013). Gaining and Leveraging Customer-Based Competitive Intelligence: The Pivotal Role of Social Capital and Salesperson Adaptive Selling Skills. Journal of the Academy of Marketing Science, 41, 91-110.

Hurley, R.F \& Hult, T. M. (1998). Innovation, Market Orientation, and Organizational Learning: An Integration and Empirical Examination. Journal of Marketing, 62 (3), 42-54.

Ibarra, H. \& Steven B. Andrews, S. B. (1993). Power, Social Influence, and Sense Making: Effects of Network Centrality and Proximity on Employee Perceptions. Administrative Science Quarterly, 38 (2) 277-303.

James, L. R., Demaree, R. G., \& Wolf, G. (1984). Estimating Within-Group Interrater Reliability with and without Response Bias. Journal of Applied Psychology, 69 (1), 85-98.

Jaworski, B. J., \& Kohli, A. (1993). Market Orientation: Antecedents and Consequences. Journal of Marketing, 57 (3), 53-70.

Joshi, A. W. (2010). Salesperson Influence on Product Development: Insights from a Study of Small Manufacturing Organizations. Journal of Marketing, 74 (1), 94-107.

Judson, K., Schoenbachler, D. D., Gordon, G. L., Ridnour, R. E., \& Weilbaker, D. C. (2006). The New Product Development Process: Let the Voice of the Salesperson Be Heard. Journal of Product \& Brand Management, 15 (3), 194-202.

Kleinbaum, D. G., Kupper, L. L., Muller, K. E., \& Nizam, A. (1998). Applied Regression Analysis and Other Multivariate Methods. Pacific Grove, CA: Thomson Publishing.

Kotler, P., Rackham, N., \& Krishnaswamy, S. (2006). Ending the War between Sales \& Marketing. Harvard Business Review, 84 (7/8), 68-78.

Krafft, M. (1999). An Empirical Investigation of the Antecedents of Sales Force Control Systems. Journal of Marketing, 63(3), 120-134.

Krasnikov, A., \& Jayachandran, S. (2008). The Relative Impact of Marketing, Research-andDevelopment, and Operations Capabilities on Firm Performance. Journal of Marketing, 72 (4), 1-11.

Krohmer, H., Homburg, C., \& Workman, J. P. (2002). Should Marketing be Cross-functional? Conceptual Development and International Empirical Evidence. Journal of Business Research, 55 (6), 451-466.

Le Bon, J., \& Dwight, M. (2006). The Impact of Individual and Managerial Factors on Salespeople's Contribution to Marketing Intelligence Activities. International Journal of Research in Marketing, 23, 395-408.

Li, T., \& Calantone, R. J. (1998). The Impact of Market Knowledge Competence on New Product Advantage: Conceptualization and Empirical Examination. Journal of Marketing, 62 (4), 13-29.

Menon, A., Bharadwaj, S. G., \& Howell, R. (1996). The Quality and Effectiveness of Marketing Strategy: Effects of Functional and Dysfunctional Conflict in Intraorganizational Relationships. Journal of the Academy of Marketing Science, 24(4), 299-313.

Narver, S. F. \& Slater, J.C. (1990). The Effect of Market Orientation on Business Profitability. Journal of Marketing, 54 (4), 20-35.

Piercy, N., Cravens, D. W., \& Lane, N. (2009). Sales Management Control and Competencies: Antecedents and Consequences. Industrial Marketing Management, 38, 459-467.

Nunnally, J. C. (1978). Psychometric Theory. 2nd edition, New York: McGraw-Hill. 
Olson, E. M., Walker, O. C., Ruekert, R. W. Ruekert, \& Bonner, J. M. (2001). Patterns of Cooperation during New Product Development among Marketing, Operations and R\&D: Implications for Project Performance. Journal of Product Innovation Management, 18 (4), 258-271.

Pfeffer, J., \& Salancik, G. R. (1978). The External Control of Organizations: A Resource Dependence Perspective. New York: Harper and Row.

Podsakoff, P. M., MacKenzie, S. B., Lee, J.-Y., \& Podsakoff, N. P. (2003). Common Method Biases in Behavioral Research: A Critical Review of the Literature and Recommended Remedies. Journal of Applied Psychology, 88 (5), 879-903.

Porter, M. E. (1980). Competitive Strategy. New York: Free Press.

Poujol, J., Fournier, C. \& Tanner, J. F. (2011). Compliance Versus Preference: Understanding Salesperson Response To Contests. Journal of Business Research, 64 (7), 664-671.

Rogelberg, S. G., \& Stanton, J. M. (2007). Understanding and Dealing with Organizational Survey Nonresponse. Organizational Research Methods, 10 (2), 195-209.

Rouziès, D., Anderson, E., Kohli, A. K., Michaels, R. E., Weitz, B. A., \& Zoltners, A. A. (2005). Sales and marketing Cooperation: a proposed framework. Journal of Personal Selling and Sales Management, 25(2), 113-122.

Ruekert, R. W., \& Walker, O. C. (1987). Marketing's Interaction with other Functional Units: A Conceptual Framework and Empirical Evidence. Journal of Marketing, 51 (1), 1-19.

Slater, S. F. \& Olson, E. M. (2000), Strategy Type and Performance: the Influence of Sales Force Management. Strategic Management Journal, 21, 813-829.

Song, M., \& Parry, M. E. (1992). The R\&D-marketing Interface in Japanese High-Technology Firms. Journal of Product Innovation Management, 9(2), 91-112.

Song, M., \& Montoya-Weiss, M. M. (2001). The Effect of Perceived Technological Uncertainty on Japanese New Product Development. Academy of Management Journal, 44 (1), 61-80.

Swink, M. (2000). Technological Innovativeness as a Moderator of New Product Design Integration and Top Management Support. Journal of Product Innovation Management, 17, 208-220.

Troy, L. C., Hirunyawipada, T., \& Paswan, A. K. (2008). Cross-Functional Cooperation and New Product Success: An Empirical Investigation of the Findings. Journal of Marketing, 72 (6), 132-146.

Verbeke, W., Dietz, B., \& Verwaal, E. (2011). Drivers of Sales Performance: a Contemporary Meta-Analysis. Have Salespeople Become Knowledge Brokers?. Journal of the Academy of Marketing Science, 39 (3), 407-428.

Verona, G. (1999). A Resource-Based View of Product Development. Academy of Management Review, 24 (1), 132-142.

Walker Jr, O. C., \& Ruekert, R. W. (1987). Marketing's role in the implementation of business strategies: a critical review and conceptual framework. Journal of Marketing, 15-33.

Weitz, B. A., \& Bradford, K. D. (1999). Personal Selling and Sales Management: a Relationship Marketing Perspective. Journal of the Academy of Marketing Science, 27 (2), 241-254. 


\section{APPENDIX \\ Measurement Instruments}

\begin{tabular}{|c|c|c|c|c|}
\hline Constructs / Items & Sources & Data Source & $\mathbf{C R}$ & AVE \\
\hline \multicolumn{5}{|l|}{ Relative New Product Advantage ${ }^{a}$} \\
\hline $\begin{array}{l}\text { Our product innovations ...: } \\
\text { 1. ... are superior to competing products in terms of meeting customer needs. } \\
\text { 2. ... provide novel product features to customers which competitors do not offer. } \\
\text { 2. ... are superior to competing products in product quality. } \\
\text { 4. ... offer unique attributes to customers not available from competing products. }\end{array}$ & $\begin{array}{c}\text { Li and Calantone } \\
\text { 1998; Song and } \\
\text { Monotoya-Weiss } \\
2001\end{array}$ & $\begin{array}{l}\text { Assessment of } \\
\text { market-side } \\
\text { respondent }\end{array}$ & .80 & .52 \\
\hline $\begin{array}{l}\text { Financial New Product Performance }{ }^{\mathrm{a}} \\
\text { Our product innovations ...: } \\
\text { 1. ... are financially very successful. } \\
\text { 2. ... have a strong and positive impact on our company's sales and profitability. }\end{array}$ & $\begin{array}{l}\text { Harmancioglu, } \\
\text { Droge, and } \\
\text { Calantone (2009) }\end{array}$ & $\begin{array}{l}\text { Assessment of } \\
\text { technical side } \\
\text { respondent }\end{array}$ & - & - \\
\hline Objective Company Performance & - & Archival Records & - & - \\
\hline \multicolumn{5}{|l|}{ R\&D-Sales Cooperation } \\
\hline $\begin{array}{l}\text { Please indicate the level of cooperation between R\&D and sales for the following activities: } \\
\text { (Likert scale: } 1=\text { very low; } 7=\text { very high) } \\
\text { 1. Analysis of customer needs. } \\
\text { 2. Generation of new-product ideas. } \\
\text { 3. Identifying opportunities for commercial application of new technology. } \\
\text { 4. Defining goals and priorities in NPD. } \\
\text { 5. Project planning and budgeting in NPD. } \\
\text { 6. Development of commercialization concepts. }\end{array}$ & $\begin{array}{l}\text { Ernst, Hoyer, and } \\
\text { Rübsaamen } \\
\qquad(2010) \\
\text { Song and Parry } \\
\text { (1992) }\end{array}$ & $\begin{array}{l}\text { Mean scores of } \\
\text { respondents from } \\
\text { market side and } \\
\text { technical side }\end{array}$ & .92 & .67 \\
\hline \multicolumn{5}{|l|}{ R\&D-Marketing Cooperation } \\
\hline $\begin{array}{l}\text { Please indicate the level of cooperation between R\&D and marketing for the following activities: } \\
\text { (Likert scale: } 1=\text { very low; } 7=\text { very high) } \\
\text { 1. Analysis of customer needs. } \\
\text { 2. Generation of new-product ideas. } \\
\text { 3. Identifying opportunities for commercial application of new technology. } \\
\text { 4. Defining goals and priorities in NPD. } \\
\text { 5. Project planning and budgeting in NPD. }\end{array}$ & $\begin{array}{l}\text { Ernst, Hoyer, and } \\
\text { Rübsaamen } \\
\qquad(2010) \\
\text { Song and Parry } \\
\quad(1992)\end{array}$ & $\begin{array}{l}\text { Mean scores of } \\
\text { respondents from } \\
\text { market side and } \\
\text { technical side }\end{array}$ & .95 & .74 \\
\hline
\end{tabular}




\section{Technological Turbulence}

1. The technology in our industry is changing constantly.

2. Technological changes provide big opportunities in our industry.

3 , It is difficult to forecast where the technology in our industry will be in 2-3 years.

Jaworski and Kohli (1993)

4. A large number of new-product ideas have been made possible through technologica breakthroughs in our industry.

5. Technological developments in our industry are rather high.

\section{Competitive Intensity}

1. Competition in our industry is cutthroat.

2. There are many "promotion wars" in our industry.

3. Our competitors are relatively strong.

4. Price competition is a hallmark of our industry.

5. One hears of a new competitive move almost every day.

\section{Differentiation Strategy ${ }^{\mathrm{a}}$}

To what extent does your business unit emphasize the following activities?

My business unit focuses on...

1. ...creating a premium product or brand image

2. ...creating competitive advantage by providing superior products.

3. ...creating superior customer value by providing premium products.

4. ...creating a premium positioning for products in the market.

\section{Cost Leadership Strategy ${ }^{\mathrm{a}}$}

To what extent does your business unit emphasize the following activities?

My business unit focuses on...

1. ...standardizing operational processes in the organization.

2. ... realizing cost savings in organizational processes.

3. ...streamlining processes in the organization.

\section{R\&D Power Distance ${ }^{\mathrm{a}}$}

1. In our department, it is expected that instructions of superiors are not questioned.

2. In our department, superiors and employees tend to have a distanced relationship.

3. In our department, an employee's influence primarily depends on his hierarchical position.

\section{R\&D Collectivism}

1. In our department, team work is strongly promoted.

2. In our department, superiors actively foster the cohesion of employees.

3. In our department, the team spirit is strong across all hierarchical levels.

Homburg,

Workman, and Krohmer (1999)
Homburg, Workman, and Krohmer (1999)

Hofstede and Bond (1984)

Assessment of technical-side respondent

market-side

Assessment of market-side respondent

Assessment of technical-side respondent 


\section{R\&D Influence on New-Product Decisions}

Please rate the influence that your department exerts on the following tasks: (constant sum scale: $0=$ no influence at all; $100=$ very strong influence)

1. DeteRMCning technical features of new products.

2. DeteRMCning the level of complexity of new products.

\section{R\&D Influence on Internal Budgeting Decisions}

Please rate the influence that your department exerts on the following tasks:

(constant sum scale: $0=$ no influence at all; $100=$ very strong influence)

1. Determining the budget and resource allocation within the business unit.

2. Determining significant strategic investments within the business unit.

\section{Product Customization $^{\mathrm{a}}$}

1. We adapt our products to individual customer requirements.

2. We offer each customer tailored products.

3. Important features of our products are specifically tied to our customers.

Top Management Support for Innovation Projects

Our top management ...

(Likert scale: 1 = very low; 7 = very high)

$1 . .$. is actively involved in innovation projects.

2. ... supports innovation projects from start to finish.

3. ... provides the required resources for innovation projects.

4. ... expects sales to fully support new products.

Firm Size

Natural logarithm of the number of employees

Industry Affiliation

Dummy variable indicating industry affiliation
Adopted from

$$
\text { Krohmer, }
$$

Homburg, and

Workman (2002)

Assessment of

technical-side

respondent

Adopted from

Krohmer,

Homburg, and

Workman (2002)

Assessment of technical-side respondent

Newly developed

Assessment of

market-side

respondent

.87

Newly developed

Assessment of

market-side

respondent

.80

Archival sources

Archival sources

a(Likert scale: 1 = totally disagree; 7 = totally agree 
Web Appendix

\section{The Contingent Roles of R\&D-Sales versus R\&D-Marketing Cooperation in New Product Development of Business-to-Business Firms}

\section{Web Appendix W1 - Overview of Methodological Robustness Checks}

\begin{tabular}{|c|c|c|}
\hline \multicolumn{3}{|c|}{ Overview of Additional Analyses and Robustness Checks } \\
\hline Type of analysis & Description/Results & Section of manuscript \\
\hline $\begin{array}{l}\text { Moderated indirect effects } \\
\text { of R\&D-Marketing/Sales } \\
\text { cooperation on financial } \\
\text { new product performance }\end{array}$ & $\begin{array}{l}\text { We conducted a moderated mediation analysis } \\
\text { assessing the indirect effects of R\&D-Sales and R\&D- } \\
\text { Marketing cooperation on financial new product } \\
\text { performance via relative new product advantage at the } \\
\text { hypothesized values of the moderators. Results of this } \\
\text { analysis show that relative new product advantage } \\
\text { indeed mediates the effects of the interaction terms on } \\
\text { financial new product performance. }\end{array}$ & p. 28 and Web Appendix W2 \\
\hline $\begin{array}{l}\text { Depiction of Interaction } \\
\text { Diagrams }\end{array}$ & - & Web Appendix W3 \\
\hline $\begin{array}{l}\text { Calculation of VIFs to } \\
\text { assess multicollinearity }\end{array}$ & $\begin{array}{l}\text { Results show VIFs between } 1.19 \text { to } 1.63 \text { indicating that } \\
\text { multicollinearity is not a major issue. }\end{array}$ & p. 35 \\
\hline $\begin{array}{l}\text { Test of potential non- } \\
\text { linear relationships }\end{array}$ & $\begin{array}{l}\text { Results indicate that R\&D-Marketing/Sales cooperation } \\
\text { do not exhibit non-linear effects on relative new product } \\
\text { advantage. }\end{array}$ & p. 35 and Web Appendix W4 \\
\hline $\begin{array}{l}\text { Model replication with hold } \\
\text { out sample }\end{array}$ & $\begin{array}{l}\text { We randomly selected two-thirds of the observations } \\
\text { from the original sample and reran Model } 1-4 \text { from } \\
\text { Table } 3 \text {. Results do not substantially deviate from the } \\
\text { initial estimations. }\end{array}$ & p. 35 and Web Appendix W5 \\
\hline $\begin{array}{l}\text { Extended correlation table } \\
\text { with interaction terms }\end{array}$ & - & Web Appendix W6 \\
\hline $\begin{array}{l}\text { Analysis of influence } \\
\text { statistic }\end{array}$ & $\begin{array}{l}\text { Based on Cook's D, results show that the data set does } \\
\text { not contain overly influential observations unduly } \\
\text { affecting results. }\end{array}$ & p. 34 \\
\hline $\begin{array}{l}\text { Estimation of additional } \\
\text { models as robustness } \\
\text { checks }\end{array}$ & $\begin{array}{l}\text { We reran Models } 1-4 \text { from Table } 3 \text { excluding either all } \\
\text { R\&D-Sales cooperation or all R\&D-Marketing } \\
\text { cooperation terms. These estimations underline the } \\
\text { robustness of the results. }\end{array}$ & p. 35 \\
\hline $\begin{array}{l}\text { Assessment of response } \\
\text { accuracy of sales vs. } \\
\text { marketing managers as } \\
\text { key informants }\end{array}$ & $\begin{array}{l}\text { Results show that marketing and sales managers (like } \\
\text { in Homburg and Jensen 2007) do not seem to differ } \\
\text { systematically in their responses. }\end{array}$ & Web Appendix W7 \\
\hline
\end{tabular}


Web Appendix W2 - Moderated Indirect Effects of R\&D-Sales and R\&D-Marketing Cooperation on Financial New Product Performance

\begin{tabular}{|c|c|c|c|c|}
\hline \multirow[b]{3}{*}{ Moderator } & \multicolumn{2}{|c|}{ Indirect Effects of R\&D-Sales Cooperation } & \multicolumn{2}{|c|}{ Indirect Effects of R\&D-Marketing Cooperation } \\
\hline & \multicolumn{2}{|c|}{ Indirect Effect: RSC $\rightarrow$ RNPA $\rightarrow$ FNPP } & \multicolumn{2}{|c|}{ Indirect Effect: RMC $\rightarrow$ RNPA $\rightarrow$ FNPP } \\
\hline & $\begin{array}{c}\text { LOW values of } \\
\text { Moderator }\end{array}$ & $\begin{array}{l}\text { HIGH values of } \\
\text { Moderator }\end{array}$ & $\begin{array}{c}\text { LOW values of } \\
\text { Moderator }\end{array}$ & $\begin{array}{l}\text { HIGH values of } \\
\text { Moderator }\end{array}$ \\
\hline $\begin{array}{l}\text { H1: Technological } \\
\text { Turbulence }\end{array}$ & $-.01 \mathrm{~ns}$ & $.08^{\star *}$ & $-{ }^{a}$ & $-^{a}$ \\
\hline H2: Competitive Intensity & $-{ }^{a}$ & $-{ }^{a}$ & $.06^{*}$ & $-.01 n s$ \\
\hline H3: Differentiation Strategy & $-.01 \mathrm{~ns}$ & $.10^{\star *}$ & - & - \\
\hline H4: Cost Strategy & $\mathrm{s}^{\mathrm{a}}$ & $-{ }^{a}$ & $-.03 n s$ & $.07^{* *}$ \\
\hline H5: R\&D Power Distance & $.01 \mathrm{~ns}$ & $.07^{\star \star}$ & $-{ }^{a}$ & $-{ }^{a}$ \\
\hline H6: R\&D Collectivism & $-a^{a}$ & $-^{a}$ & $-.02 n s$ & $.07^{\star \star}$ \\
\hline $\begin{array}{l}\text { H7: R\&D Influence on New } \\
\text { Product Decisions }\end{array}$ & $-^{a}$ & $-^{a}$ & $-.01 \mathrm{~ns}$ & $.05^{\star}$ \\
\hline $\begin{array}{l}\text { H8: R\&D Influence on } \\
\text { Internal Budgeting } \\
\text { Decisions }\end{array}$ & $-.02 \mathrm{~ns}$ & $.08^{\star *}$ & $-{ }^{a}$ & $-{ }^{a}$ \\
\hline
\end{tabular}




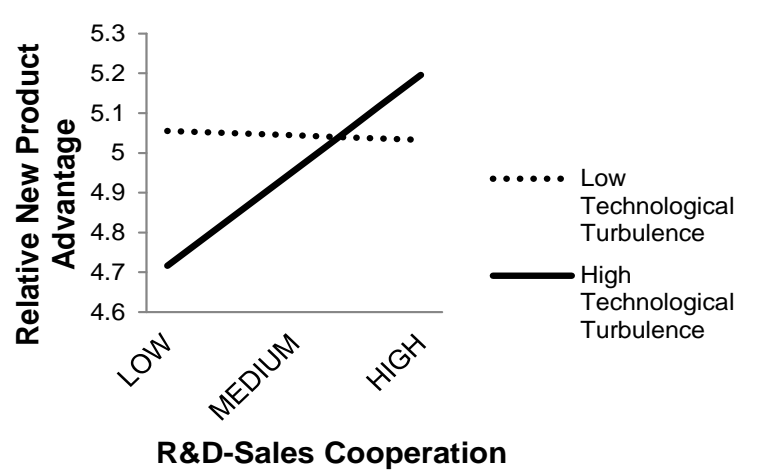

\section{Web Appendix W3 - Interaction Diagrams}
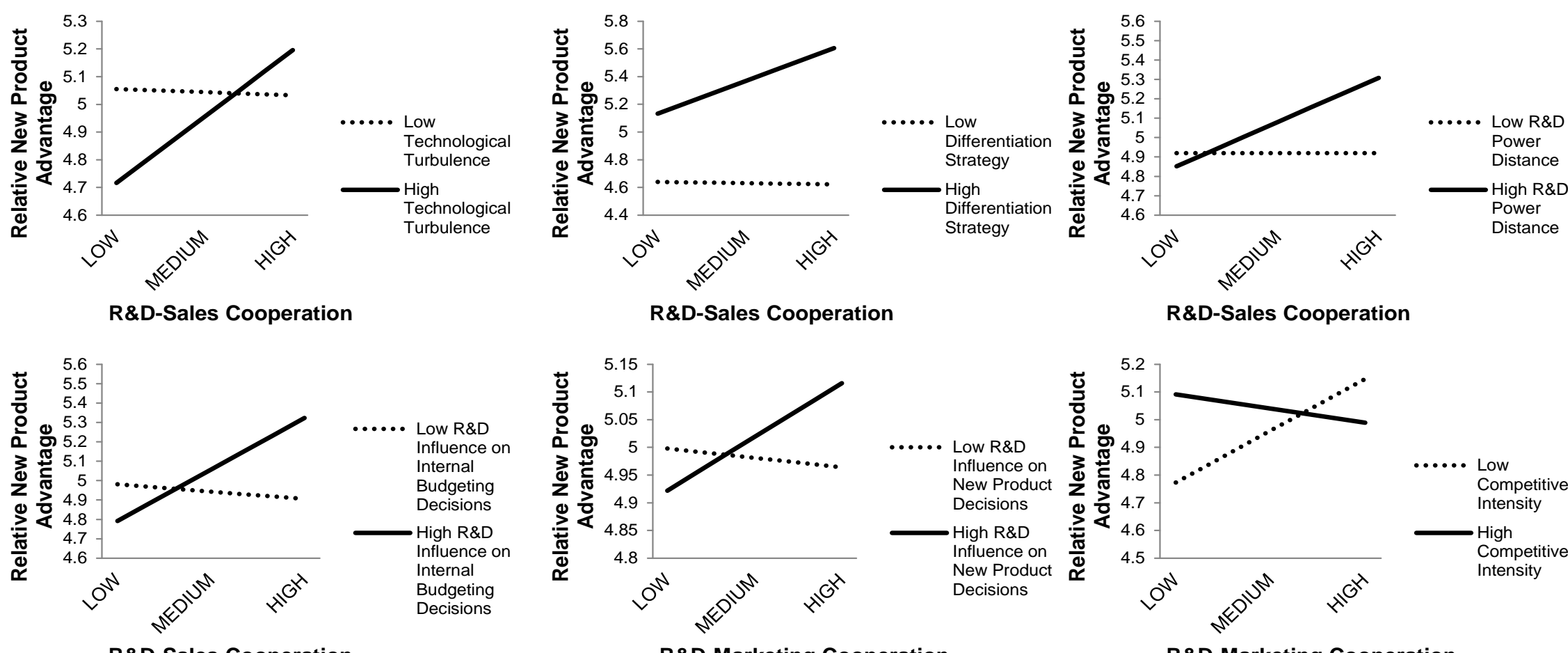
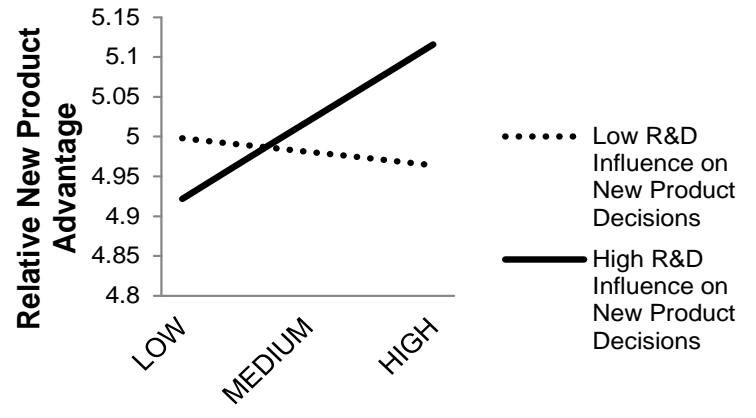

R\&D-Marketing Cooperation

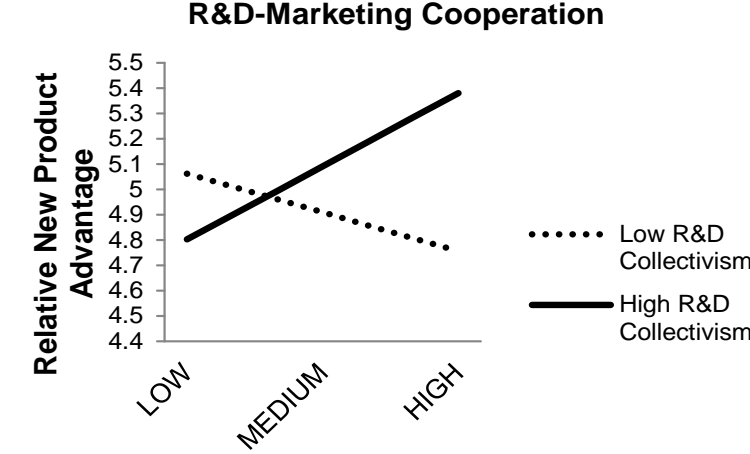

R\&D-Marketing Cooperation

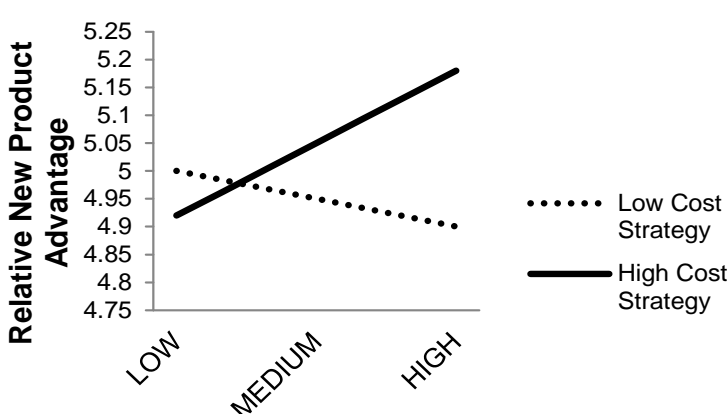

R\&D-Marketing Cooperation
Low R\&D Internal Decisions

High R\&D Internal Budgeting
Decisions

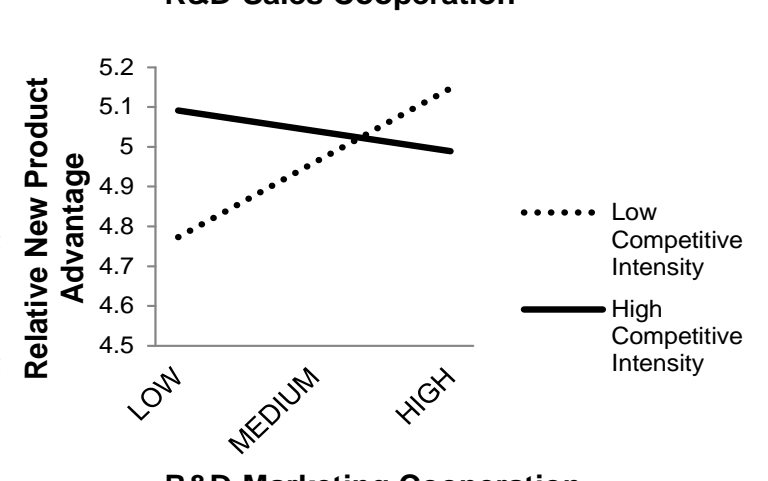

R\&D-Marketing Cooperation 


\section{Web Appendix W4 - Testing for Potential Nonlinear Relationships of R\&D- Sales/Marketing Cooperation on Relative New Product Advantage}

To explore non-linearity in our model, we examine whether R\&D-Sales cooperation (RSC) or R\&D-Marketing cooperation (RMC) exhibit quadratic or cubic effects on relative new product advantage. Results of our analysis indicate that RSC and RMC have a linear relationship with relative new product advantage as the non-linear terms are barely significant and the linear models exhibit a better fit with the data.

\begin{tabular}{|c|c|c|c|}
\hline & \multicolumn{3}{|c|}{ R\&D-Sales Cooperation } \\
\hline & \multicolumn{3}{|c|}{ Dependent Variable: Relative New Product Advantage } \\
\hline $\begin{array}{l}\text { Independent } \\
\text { Variable }\end{array}$ & Linear Model & Quadratic Model & Cubic Model \\
\hline $\begin{array}{l}\text { R\&D-Sales } \\
\text { Cooperation }\end{array}$ & $.27^{\star \star \star}$ & $.31^{\star \star \star}$ & 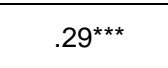 \\
\hline $\begin{array}{c}\text { R\&D-Sales } \\
\text { Cooperation² }^{2}\end{array}$ & - & $.11^{*}$ & $.12^{\star}$ \\
\hline $\begin{array}{c}\text { R\&D-Sales } \\
\text { Cooperation }{ }^{3}\end{array}$ & - & - & $.02 \mathrm{~ns}$ \\
\hline $\mathrm{R}^{2}$ & .07 & .08 & .08 \\
\hline$\Delta R^{2}$ & - & ns & ns \\
\hline F-Value & 18.23 & 11.06 & 7.35 \\
\hline
\end{tabular}

R\&D-Marketing Cooperation

\begin{tabular}{|c|c|c|c|}
\hline & \multicolumn{3}{|c|}{ R\&D-Marketing Cooperation } \\
\hline & \multicolumn{3}{|c|}{ Dependent Variable: Relative New Product Advantage } \\
\hline $\begin{array}{c}\text { Independent } \\
\text { Variable }\end{array}$ & Linear Model & Quadratic Model & Cubic Model \\
\hline $\begin{array}{l}\text { R\&D-Marketing } \\
\text { Cooperation }\end{array}$ & $.16^{\star \star}$ & $.17^{\star *}$ & $.11 \mathrm{~ns}$ \\
\hline $\begin{array}{l}\text { R\&D- Marketing } \\
\text { Cooperation² }\end{array}$ & - & $.11^{\star}$ & $.10 \mathrm{~ns}$ \\
\hline $\begin{array}{l}\text { R\&D- Marketing } \\
\text { Cooperation }^{3}\end{array}$ & - & - & $.06 n s$ \\
\hline $\mathrm{R}^{2}$ & .02 & .03 & .03 \\
\hline$\Delta \mathrm{R}^{2}$ & - & ns & Ns \\
\hline F-Value & 5.83 & 4.41 & 2.97 \\
\hline
\end{tabular}

Notes. The table reports standardized coefficients. ${ }^{\star} p<.1,{ }^{\star \star} p<.05,{ }^{\star \star \star} p<.01$ (two-tailed). 
Web Appendix W5 - Assessment of Estimation Models on Holdout Sample

Dependent Variable: Relative New Product Advantage

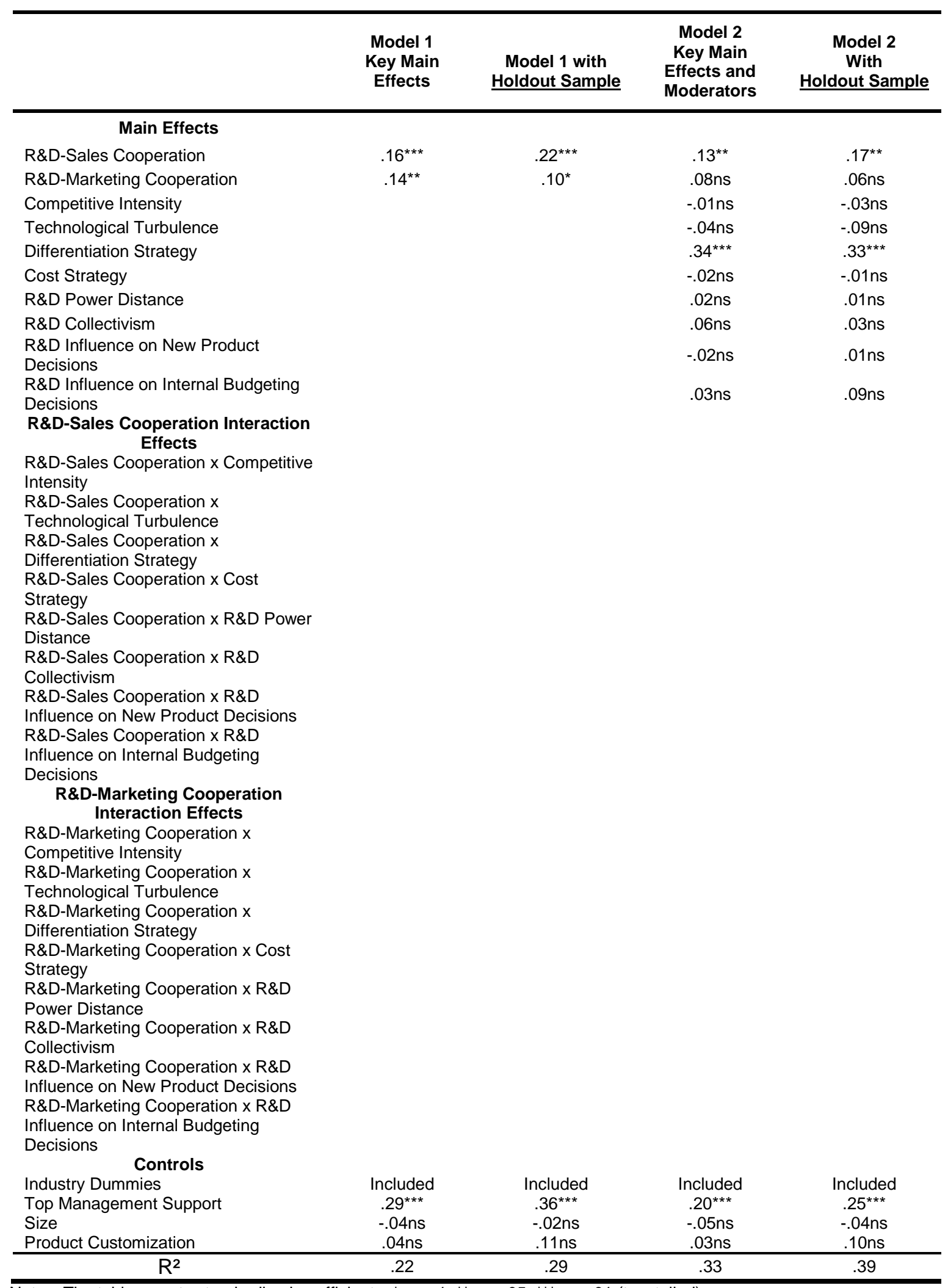

Notes. The table reports standardized coefficients. ${ }^{*} p<.1,{ }^{\star \star} p<.05,{ }^{\star \star \star} p<.01$ (two-tailed). 
Dependent Variable: Relative New Product Advantage

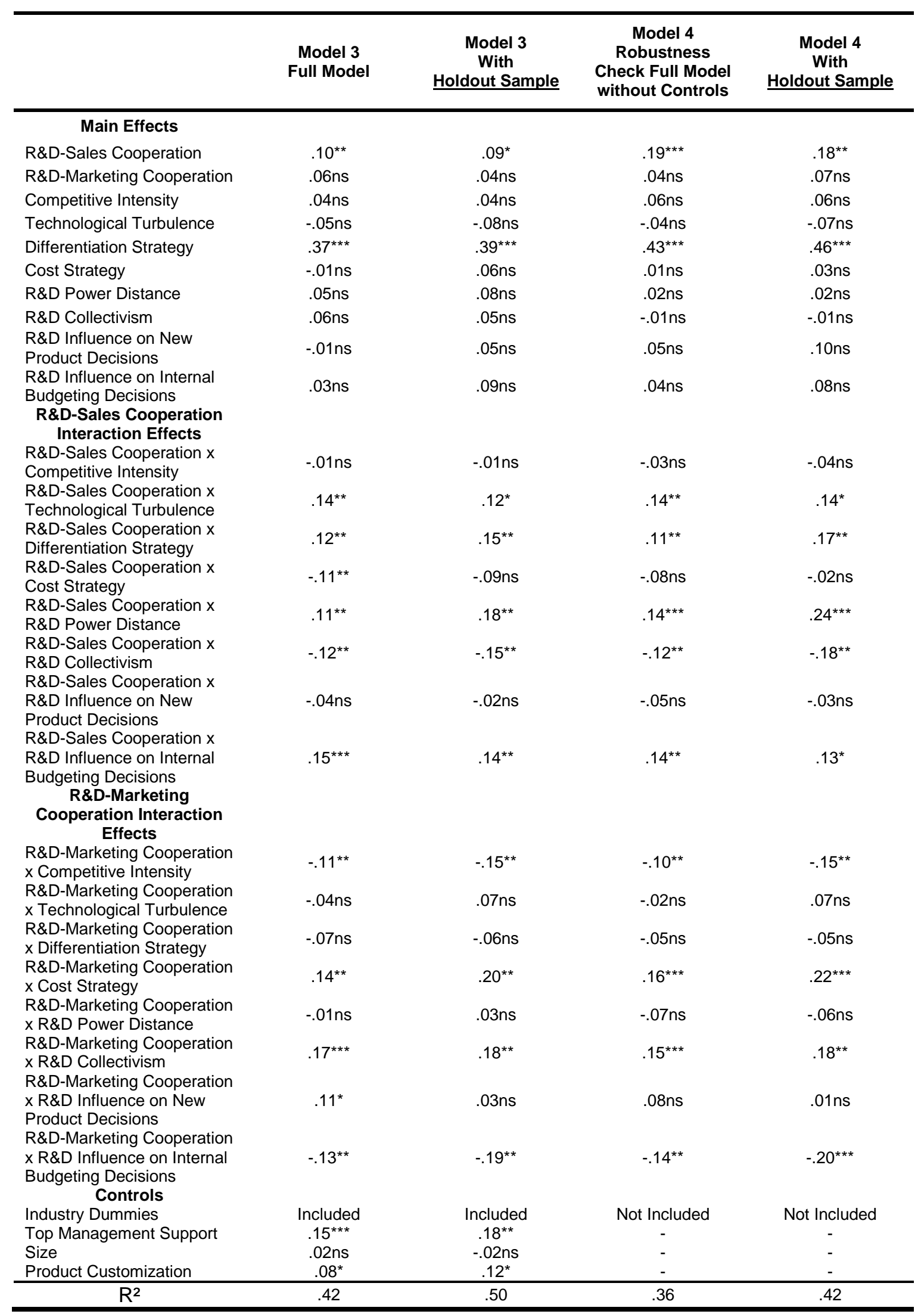

Notes. The table reports standardized coefficients. ${ }^{\star} p<.1,{ }^{\star \star} p<.05,{ }^{\star \star \star} p<.01$ (two-tailed). 
Web Appendix W6 - Full Correlation Table

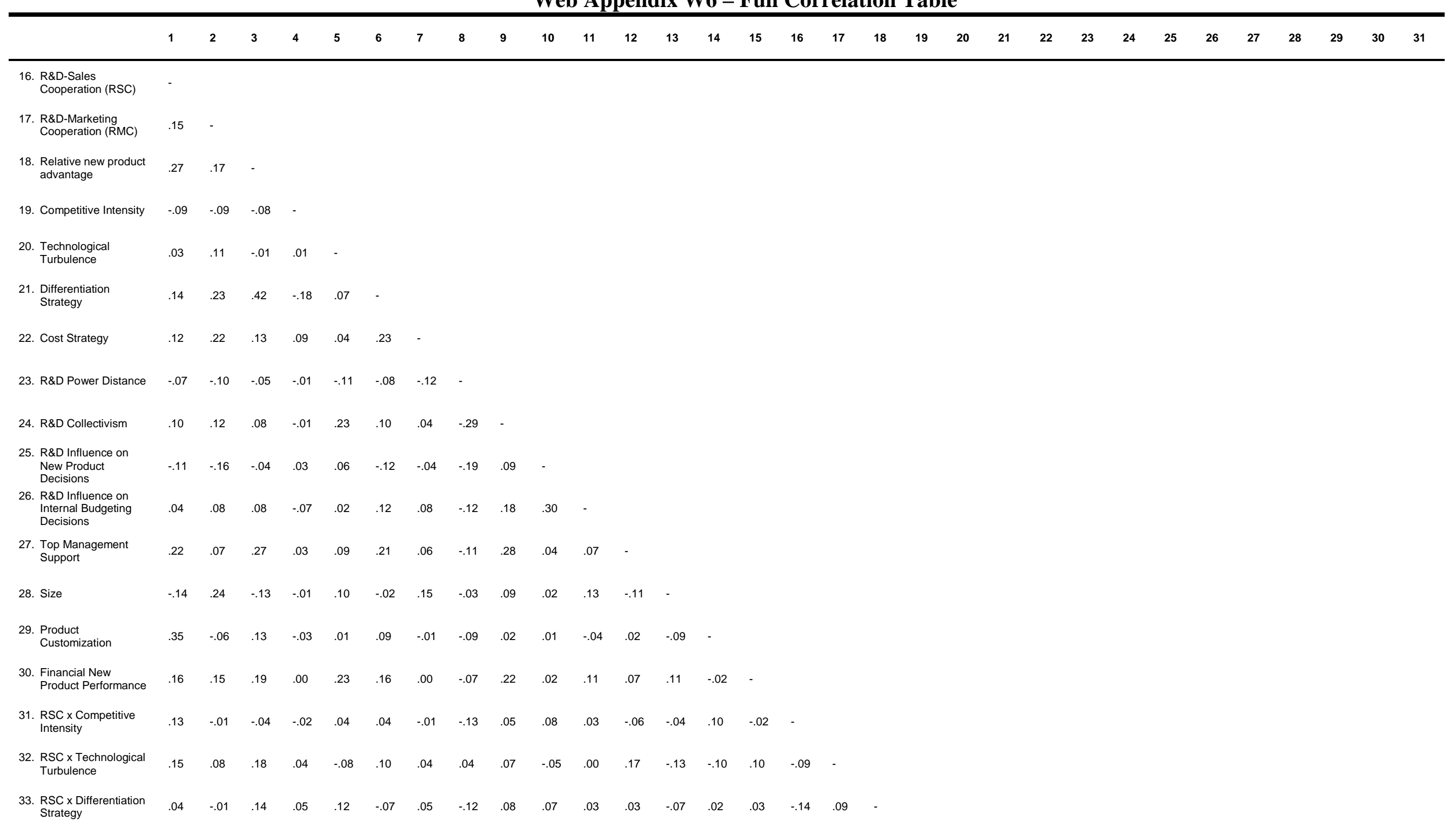




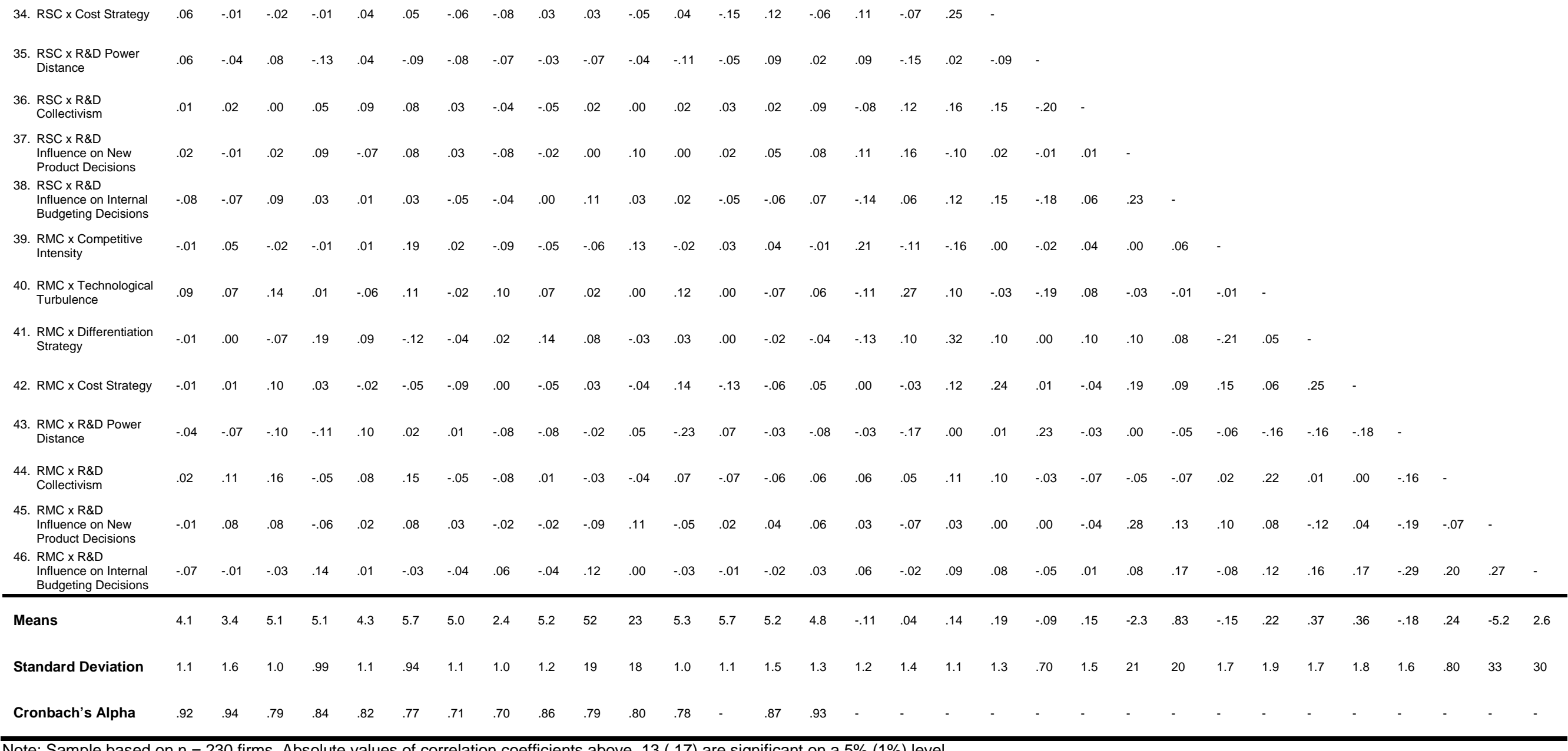




\section{Web Appendix W7- Assessment of Response Accuracy of Sales vs. Marketing Managers as Key Informants}

For all variables in the conceptual model provided by the market-side respondent (R\&D-Sales cooperation, R\&D-Marketing cooperation, differentiation strategy, cost leadership strategy, relative new product advantage), we tested whether in the marketing or sales manager subsample perceptual congruence differs between the market-side and technical-side respondent. Therefore, we calculated the absolute deviation between the technical-side respondent and market-side respondent for the respective variables. We then regress this score on a binary variable (coded $1=$ marketing manager $0=$ sales manager). The following table presents the results, showing that the congruence between market-side respondent and technical-side respondent does not differ for marketing and sales managers.

\begin{tabular}{|c|c|c|c|c|c|}
\hline & \multicolumn{5}{|c|}{ Deviation between Market-Side Respondent and Technical-Side Respondent } \\
( $\beta$ standardized coefficient)
\end{tabular}

ns = not significant 
Web Appendix W8- Overview of introductory study With whom should the research and development department collaborate to ensure the success of new product in your view?

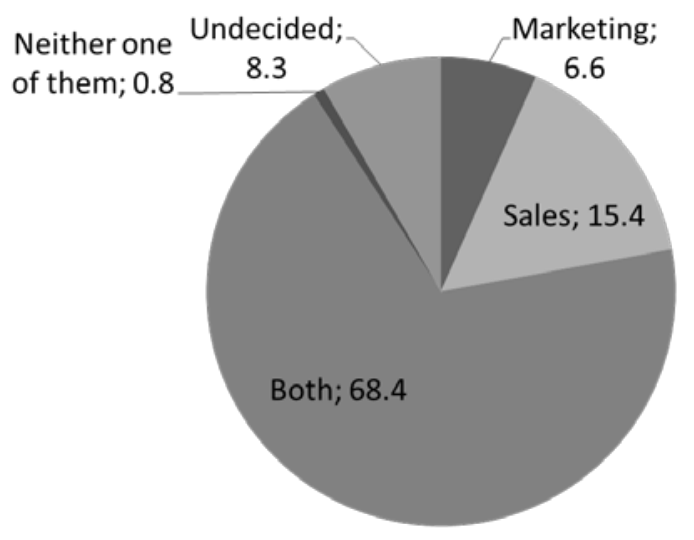

\begin{tabular}{llc}
\hline Category & Variable & Distribution \\
\hline \multirow{2}{*}{ Country } & United States & $70(35.0 \%)$ \\
& Germany & $130(65.0 \%)$ \\
\hline \multirow{4}{*}{ Retail } & Automobile & $43(21.5 \%)$ \\
industries & Jewelry & $28(14.0 \%)$ \\
& Furniture & $39(19.5 \%)$ \\
& Electronics & $34(17.0 \%)$ \\
& Fashion & $56(28.0 \%)$ \\
\hline \multirow{2}{*}{ Demographics } & Gender & 97 male $(48.5 \%)$ \\
& Average age & 103 female $(51.5 \%)$ \\
& Average years of job experience & 39.0 \\
\hline
\end{tabular}

